Article

\title{
Characterizing Meteorological Droughts in Nepal: A Comparative Analysis of Standardized Precipitation Index and Rainfall Anomaly Index
}

\author{
Anil Aryal ${ }^{1, *}$, Manisha Maharjan ${ }^{2}$, Rocky Talchabhadel ${ }^{3}$ (D) and Bhesh Raj Thapa ${ }^{4}$ \\ 1 Interdisciplinary Center for River Basin Environment (ICRE), University of Yamanashi, Kofu 400-8510, Japan \\ 2 Independent Researcher, Kofu 400-0008, Japan; maneesha064@gmail.com \\ 3 Texas A\&M AgriLife Research, Texas A\&M University, El Paso, TX 79927, USA; \\ rocky.talchabhadel@ag.tamu.edu \\ 4 Department of Civil Engineering, Universal Engineering and Science College, Lalitpur 44700, Nepal; \\ bhesh@smartphones4water.org \\ * Correspondence: aanil@yamanashi.ac.jp
}

check for

updates

Citation: Aryal, A.; Maharjan, M.;

Talchabhadel, R.; Thapa, B.R.

Characterizing Meteorological

Droughts in Nepal: A Comparative

Analysis of Standardized

Precipitation Index and Rainfall

Anomaly Index. Earth 2022, 3,

409-432. https://doi.org/10.3390/ earth3010025

Academic Editor: Hossein Bonakdari

Received: 30 January 2022

Accepted: 2 March 2022

Published: 4 March 2022

Publisher's Note: MDPI stays neutral with regard to jurisdictional claims in published maps and institutional affiliations.

Copyright: (C) 2022 by the authors. Licensee MDPI, Basel, Switzerland. This article is an open access article distributed under the terms and conditions of the Creative Commons Attribution (CC BY) license (https:// creativecommons.org/licenses/by/ $4.0 /)$.

\begin{abstract}
Drought is an environmental disaster related to the extremes (on a drier side) in hydrometeorology. The precipitation amount modulates drought in Nepalese river basins. It is vital for efficient water resources management to quantify and understand drought. This paper aims to characterize the droughts in Nepal based on standard precipitation index (SPI) and rainfall anomaly index (RAI) using daily precipitation data and assess their impacts on annual crop yields. We used 41 years (1975-2015) of daily precipitation data to compute monthly means and then the drought indices, namely, SPI and RAI, at 123 stations across Nepal. Results showed that the northwest and eastern regions experienced drought compared to other regions, although the severity and duration were shorter. For stations 101 and 308, we found extreme drought events after 2005 for SPI-1, SPI-3, and SPI-6. However, for SPI-6, extreme drought was also observed in 1989 and 1994 at both stations. The year 1992 was one of the severest drought years for the western and northwest regions, where the severity crossed more than -2.0 for all SPI months. Similar to SPI, RAI also revealed a similar degree of drought in the country. RAI showed that the eastern region depicted a higher degree of severity of drought compared to other areas beyond 2004. The lesser severity is also seen in the far west part beyond 2005. The results showed that SPI and RAI could equally be used to analyze drought severity. More frequent drought incidents have been observed after 2010 at all the considered precipitation stations. With the increase in the drought severity, the crop yield (such as paddy, maize, barley, millet, and wheat) has been directly impacted. These results might be significant for planning water resource and irrigation water management systems.
\end{abstract}

Keywords: crop yield; drought; rainfall anomaly index; standardized precipitation index; water resource management

\section{Introduction}

Drought is a recurrent natural hazard caused by precipitation deficiency resulting in damage to crops, water resources, economies, and human lives [1] over an extended space-time domain. Drought has a significant impact on various aspects of the global ecosystem [2-5]. The drought phenomena can be meteorological, hydrological, agricultural, or/and socio-economic [6-8]. Meteorological drought is defined as the lack of precipitation over a region for a more extended period, and hydrological drought is related to the low water supply in streams, reservoirs, and groundwater levels [9]. Agricultural drought usually refers to declining soil moisture and consequent crop failure without reference to surface water resources. In addition, socioeconomic drought is associated with the inability of water resources systems to meet water demands [10,11]. A significant relationship 
between meteorological drought and other droughts could be found [12]. Propagation of the meteorological drought to other drought forms is characterized by essential features such as pooling, attenuation, lag, and lengthening $[13,14]$, emphasizing its importance.

The spatial variation of drought can vary from global to local scales [15]. A drought may last from a month to a decade [16], affecting the ecosystem balance [17]. In addition, drought might affect various socio-economic sectors, including agriculture, hydropower, inland navigation, and even tourism [18]. Thus, it is evident to characterize the spatiotemporal variations in drought for effective water resources management. The quantitative analysis of drought can be done by estimating different drought indices, such as the Palmer drought severity index (PDSI), standardized precipitation index (SPI), rainfall anomaly index (RAI), crop water stress index (CWSI), Palmer hydrological drought index (PHDI), streamflow drought index (SDI), normalized difference water index (NDWI), vegetation condition index (VCI), and normalized difference vegetation index (NDVI) [6,19-21]. These indices have been used to assess the duration and intensity of extreme precipitation at different temporal scales [22,23]. Extreme precipitation events such as heavy and low rainfall are analyzed based on the daily rainfall events. In contrast, long-term drought events are assessed based on monthly and annual rainfall to ensure water scarcity.

Drought indices, specifically, SPI [24] and RAI [25], are simple to use yet robust on performance. In addition, they only need rainfall data. SPI has been widely applied in various studies globally and regionally [26-30]. SPI has numerous advantages over other drought indices [31], including the data required for temporal and spatial characteristics on application [32]. The SPI has also been used to analyze projection results [33,34], whereas RAI receives less attention [35]. Several studies have been carried out to check SPI and RAI [36-38]. A comparison of model results with the observed data can be made using standardized precipitation anomalies [38]. Compared to SPI, RAI poses a higher degree of transparency and is less complicated in mathematical computation [36]. RAI can also be computed at identical time scales to SPI with a similar degree of robustness.

Drought in Nepal is mostly characterized by meteorological events caused by late monsoon onset or/and inadequate rainfall distribution [39]. Such poor rainfall distribution has affected both agricultural and non-agricultural sectors. Importantly, agriculture is the country's critical economic activity. The yield of the major crops decreased to 56,000 metric tons in 2013 compared to 727,460 metric tons in 1982 [40,41]. The drought of winter 2008-2009 affected most of the country's districts, resulting in a significant crop yield reduction [42]. Drought in Nepal has equally affected the non-agricultural sectors, such as human health [42] and migration of the males searching for jobs [39]. Adhikari et al. [39] further reported that Nepal received several meteorological droughts during 1970-1990, and winter droughts during 2002-2004 attributed to the reduction in precipitation by 50\%. Between 2005 and 2010, the country's hilly region had dry spells and wet monsoon, reducing the crop yield [39].

Nepal receives most of (about 80\%) its rainfall in the monsoon season. The rainfall variability plays a key indicator in the country's dry and wet conditions [43,44]. Approximately $60 \%$ of Nepal's irrigable land depends on monsoon rainfall. An insufficient amount of meteorological, hydrological, and water resource infrastructure makes it more challenging to deal with droughts. Irregularity in monsoon seasons has also acted as a catalyst for low crop yield. In addition, the soil moisture index (SMI) plays a crucial role in the planning of the irrigation facilities at the field level [43]. All droughts are mainly related to meteorological and soil moisture conditions, affecting irrigation facilities' planning at the field level to achieve optimum crop production. Thus, characterizing the drought condition in spatial and temporal constraints can provide a sound understanding of different droughts and their relationship in an agricultural country like Nepal. Few studies on meteorological drought are conducted in Nepal using SPI on either a catchment or regional scale, for instance, Sigdel and Ikeda [45] and Dahal et al. [46]. The studies in the past were conducted either at the local level only or have used limited meteorological data in both time and space. The current study aims to complement past studies and fulfill these research gaps. Further, 
the current study also tests the suitability of RAI and SPI to characterize the drought events in the case of Nepal; it is the first of this kind of study in the country.

In this context, spatio-temporal characterization of drought using different techniques is essential for crop planning, irrigation scheduling, irrigation infrastructure development, and planning of irrigation facilities. That information helps the policymakers, farmers, and researchers for early planning of the crop calendar and associated irrigation scheduling in that area. Furthermore, proper planning could increase crop production, retain the rural area population, and motivate them to engage in agriculture. Hence, this study uses long-term rainfall data to characterize the drought using SPI and RAI techniques across Nepal.

\section{Materials and Methods}

\subsection{Study Area}

The study area lies between $26^{\circ} 12^{\prime} \mathrm{N}$ and $30^{\circ} 27^{\prime} \mathrm{N}$ latitudes and $80^{\circ} 04^{\prime} \mathrm{E}$ and $88^{\circ} 12^{\prime} \mathrm{E}$ longitudes. The country covers $147,516 \mathrm{~km}^{2}$, ranging from $60 \mathrm{~m}$ in the south to $8848 \mathrm{~m}$ above mean sea level in the north, thereby demonstrating high climate variability. The country is divided into seven provinces: (1) Province 1, (2) Madhesh, (3) Bagmati, (4) Gandaki, (5) Lumbini, (6) Karnali, and (7) Sudurpaschim, extending from east to west (Figure 1). The country is rich in water resources reflecting the importance of water-intensive services such as agriculture production, inland navigation, and hydropower production. Almost two-thirds of the population is engaged in agriculture, although it is in a low development stage with low competitiveness and low productivity [47]. One of the significant enabling environments for enhancing agricultural productivity is irrigation facilities like improved seeds, fertilizers, innovative tools, and farm mechanization techniques.

In Nepal, approximately $40 \%$ of the total agricultural areas are irrigated, and the rest of the land's agricultural activities solely depends on the rainfall. Karnali, Narayani, and Koshi are the major rivers that flow within the country with high river flow and potential for navigation. The country also poses medium-sized rivers such as Bagmati, Babai, Rapti, Kamala, Kankai, etc., which act as a source of surface water for irrigation and hydropower generation. The country has six seasons: spring (mid-March-mid-May, Basanta), summer (mid-May-mid-July, Grishma), rainy (mid-July-mid-September, Barsha), autumn (midSeptember-mid-November, Sharad), pre-winter (mid-November-mid-January, Hemanta), and winter (mid-January-mid-March, Shishir), with spatial and temporal variability on the amount of the rain received. The rainy (Barsha) season receives almost $80 \%$ of the rainfall, leaving the remaining seasons as moderate and lesser rainfall seasons. In the Tarai (southern Nepal), summer temperatures exceed $37^{\circ} \mathrm{C}$ and are higher in some areas, and winter temperatures range from $7^{\circ} \mathrm{C}$ to $23^{\circ} \mathrm{C}$ in Tarai. In mountainous regions, hills, and valleys, summers are temperate, whereas winter temperatures can plummet below zero.

\subsection{Data}

We collected the required rainfall data from the Department of Hydrology and Meteorology (DHM), Kathmandu, Nepal, at a daily time scale for 41 years (1975-2015). We then filled in the missing daily rainfall data using an average station approach, one of the popular methods used in the Himalayan region. The daily data are then converted to a monthly time scale for calculating the SPI values in R-programming language.

Similarly, we obtained the annual crop data from the Ministry of Agricultural Development for 1980-2011. In Nepal, cereal crops such as maize, paddy, millet, barley, and others are prepotent. Among these, paddy is water intensive and depends on rainfall and irrigation infrastructures. Paddy is grown all across the country but is more produced in the Tarai (southern belt) and hilly regions (northern belt). The Tarai region is also considered the food basket of the country. The temporal change in the rainfall pattern alters rice production in Tarai. Millet and wheat require a temperate and tropical climate for cultivation. The crops like maize and millet are grown in Tarai and Hilly regions during dry seasons. We chose the crops of paddy, maize, wheat, and barley for the analysis as they 
are grown widely across the country throughout the year. The crop yield of any region is more dependent on the amount of rainfall, land use and management practices, and irrigation systems.

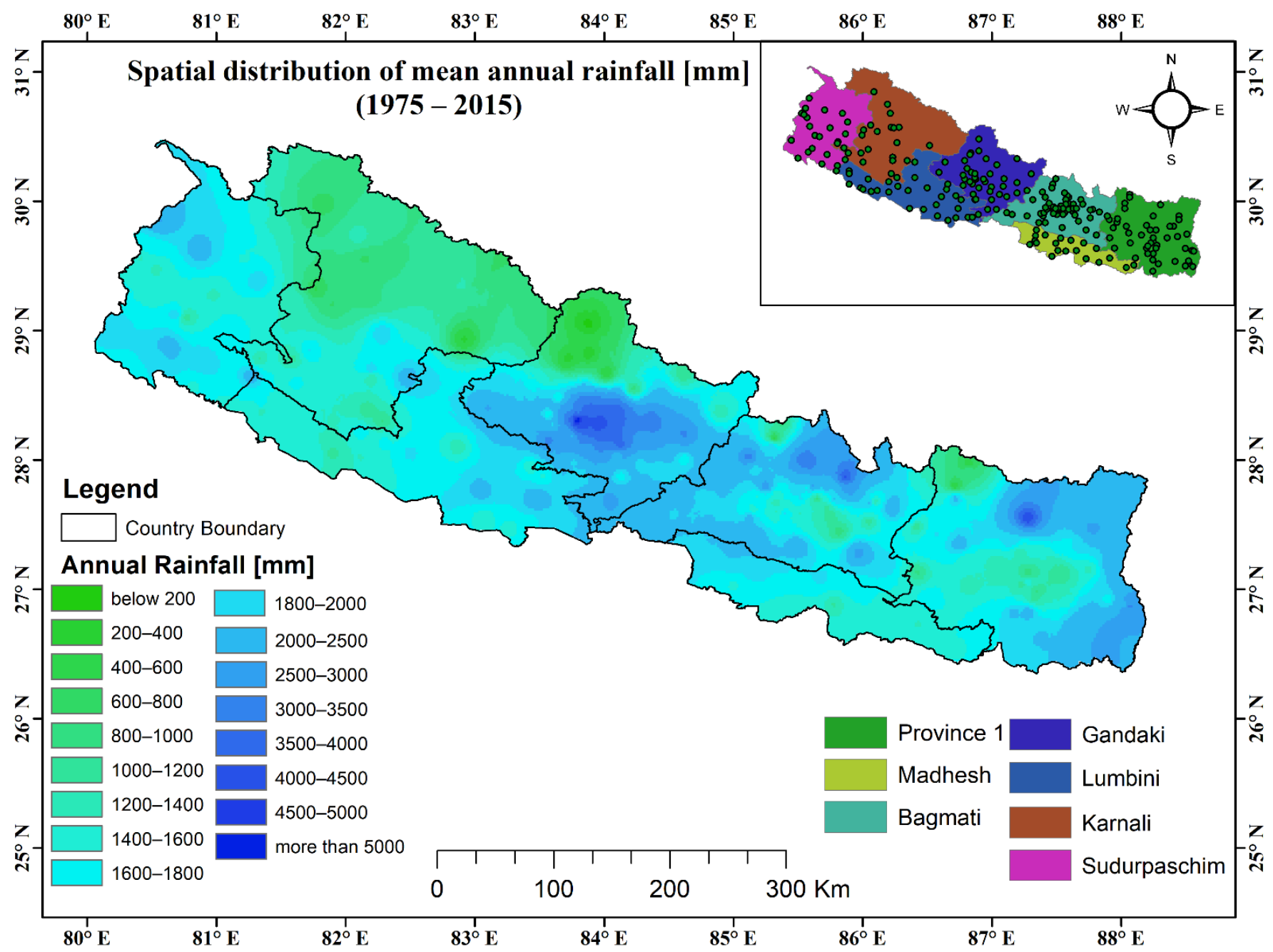

Figure 1. Spatial distribution of mean annual rainfall across different provinces of Nepal for 1975-2015. The inset shows the meteorological (rainfall) stations used for analysis.

\subsection{Methods}

We show the overall methodological framework that characterizes the meteorological drought of Nepal in Figure 2. We analyzed the impact of meteorological droughts on different major crops such as paddy, maize, barley, and millet at various districts in Nepal. The detailed description and calculation method of the approaches used in the current study are described in subsequent sections.

\subsubsection{Standardized Precipitation Index (SPI)}

Standardized precipitation index (SPI) is a broadly used drought index to characterize meteorological drought and was developed by Mckee et al. [24]. The SPI application is not limited to drought only; itis also used for frequency analysis and climate impact studies. As per the World Meteorological Organization (WMO) recommendation, SPI is a meteorological drought index in which precipitation is the primary influencing climatic parameter [48]. The SPI quantifies observed precipitation as a standardized departure from a selected probability distribution function that models the raw precipitation data. The raw precipitation data are typically fitted to a gamma or a Pearson type III distribution and then 
transformed to a normal distribution. Therefore, the SPI values can be interpreted as the number of standard deviations the observed anomaly deviates from the long-term mean. It uses monthly precipitation aggregates at various time scales $(1,3,6,12,18$, and 24 months, etc.). The SPI value ranges from -2.00 (dry) to +2.00 (wet). As a result, the index shows a different degree of severity, as represented in Table 1. The calculation is based on the gamma distribution. We used the SPEI package in R-programming software to calculate SPI at various periods [49].

Meteorological Drought

Standardized Precipitation Index (SPI),

Standardized Precipitation Evapotranspiration Index (SPEI),

Rainfall Anomaly Index (RAI), Aridity Anomaly Index (AAI)

\begin{tabular}{|l|c|}
\hline Standardized Precipitation Index (SPI) & R-Programing Language \\
Rainfall Anomaly Index (RAI) & Microsoft Excel \\
\hline
\end{tabular}

Standardized Precipitation Index (SPI)

Rainfall Anomaly Index (RAI)

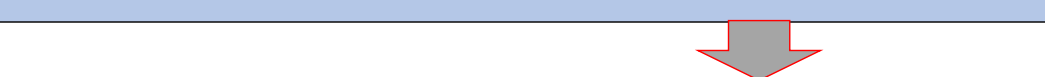

Temporal (1975-2015)

Spatial (Whole Nepal)
Data required Precipitation
Gamma Distribution Anomaly based classification

\section{Crops:}

Rice, Maize, Barley, Millet

Figure 2. An overall methodological framework to access the meteorological drought characteristics in Nepal using two drought indices.

Table 1. Degree of severity based on standardized precipitation index (SPI).

\begin{tabular}{cccc}
\hline Category & Values & Category & Values \\
\hline Extreme wet & $\geq 2.00$ & Moderate drought & $-1.0 \sim-1.49$ \\
Severe wet & $1.50 \sim 1.99$ & Severe drought & $-2.00 \sim-1.50$ \\
Moderate wet & $1.0 \sim 1.49$ & Extreme drought & $\leq-2.00$ \\
Near normal & $-0.99 \sim 0.99$ & & \\
\hline
\end{tabular}

\subsubsection{SPI Calculation}

We computed the SPIs for both space and time using the method developed by Mckee et al. [24]. The method uses monthly precipitation aggregates at various time scales $(1,3,6,12,18$, and 24 months, etc.). For an instance, to calculate SPI for a 3-month time scale, the precipitation accumulated from month $\mathrm{j}-2$ to month $\mathrm{j}$ is summed and attributed to month $\mathrm{j}$. At this time scale, the first two months of the data time series are missing. Then, the normalization procedure is conducted, in which an appropriate probability density function is first fitted to the long-term time series of aggregated precipitation. Finally, the fitted function is used to calculate the cumulative distribution of the data points, which are finally transformed into standardized normal variates. This procedure is repeated for all needed time scales. The maximum-likelihood (ML) estimation method [50] was used to fit 
gamma probability distribution functions to each time series. The detail of the computation is given by Equations (1)-(5) as follows:

The probability density function of the gamma distribution is defined as

$$
g(x)=\frac{1}{\beta^{\alpha} \Gamma(\alpha)} x^{\alpha-1} e^{-x / \beta}, \text { for } x>0
$$

where $x>0$ is the amount of precipitation, $\alpha>0$ and $\beta>0$ are the shape and scale parameters, respectively, and $\Gamma(\alpha)$ is the gamma function. Detailed explanations on the gamma distribution can be found in Lloyd-Hughes and Saunders [51] and Guttman [26].

To fit the distribution parameters, $\alpha$ and $\beta$ are estimated from the sample data using the approximation for ML defined by Thom [52] which are given by:

$$
\begin{gathered}
\hat{\alpha}=\frac{1}{4 A}\left(1+\sqrt{1+\frac{4 A}{3}}\right) \text { and } \\
\hat{\beta}=\bar{x} / \hat{\alpha}
\end{gathered}
$$

where $\bar{x}$ is mean precipitation and $A$ is given by $A=\ln (\bar{x})-n^{-1} \sum \ln (x)$.

For a given month and time scale, the cumulative probability $G(x)$ of an observed amount of precipitation is given by

$$
G(x)=\frac{1}{\hat{\beta}^{\hat{\alpha}} \Gamma(\hat{\alpha})} \int_{0}^{x} x^{\hat{\alpha}} e^{-x / \hat{\beta}} d x
$$

Let us consider $t=x / \hat{\beta}$, the expression is reduced to the incomplete gamma function as follows:

$$
G(x)=\frac{1}{\Gamma(\hat{\alpha})} \int_{0}^{x} t^{\hat{\alpha}-1} e^{-1} d t
$$

The gamma distribution is not defined for $x=0$, and, the probability of zero precipitation $q=P(x=0)$ being positive, the actual probability of non-exceedance $H(x)$ is calculated as follows:

$$
H(x)=q+(1-q) G(x)
$$

Finally, the cumulative probability distribution $H(x)$ is transformed into the standard normal distribution to yield the SPI.

\subsubsection{Rainfall Anomaly Index (RAI)}

The RAI, developed by Rooy [25], is used to classify the positive and negative severities in rainfall anomalies. It is also considered an index of remarkable procedural simplicity (like SPI) because it requires only precipitation data [38,53]. Araújo et al. [54] employed the RAI concept to analyze the climatology at the Paraiba river basin. Similarly, Sanches et al. [55] also applied the RAI concept to analyze the precipitation variability for more than seven decades (1928-2009) in Alegrete. These studies concluded that RAI could be a vital tool in analyzing the precipitation data over the study area from the research results. Similarly, Santos et al. [56] utilized RAI to analyze the Mamanguape River basin's climate. They found that the river basin can be divided into three regions in terms of precipitation patterns. The research results further concluded that RAI is an alternative tool in observing the area's precipitation pattern. The degree of severity for the RAI index is shown in Table 2. The degree of severity varies from -4 (extremely dry) to +4 (extremely humid/wet). We used Microsoft Excel to compute the RAI values using Equations (6) and (7). 
Table 2. The intensity of the rainfall anomaly index (RAI).

\begin{tabular}{cccc}
\hline Category & Values & Category & Values \\
\hline Extreme humid & $>4.00$ & Dry & $-2.0 \sim 0.0$ \\
Very humid & $2.0 \sim 4.0$ & Very dry & $-4.0 \sim-2.0$ \\
Humid & $0.0 \sim 2.0$ & Extreme dry & $<-4.0$ \\
\hline
\end{tabular}

\subsubsection{RAI Calculation}

We computed RAI for both annual and monthly periods using Equations (6) and (7):

$$
\begin{aligned}
\text { RAI } & =3\left[\frac{\mathrm{N}-\overline{\mathrm{N}}}{\overline{\mathrm{M}}-\overline{\mathrm{N}}}\right] \text { for the positive anomaly } \\
\text { RAI } & =-3\left[\frac{\mathrm{N}-\overline{\mathrm{N}}}{\overline{\mathrm{X}}-\overline{\mathrm{N}}}\right] \text { for the negative anomaly }
\end{aligned}
$$

where $\mathrm{N}$ is the current monthly/seasonal/annual precipitation;

$\overline{\mathrm{N}}$ is the average monthly/seasonal/annual precipitation of historical series;

$\overline{\mathrm{M}}$ is the average of ten highest monthly/seasonal/annual precipitations;

$\bar{X}$ is the average of ten lowest monthly/seasonal/annual precipitations;

$\mathrm{N}-\overline{\mathrm{N}}$ represents the positive anomaly and negative anomaly based on positive or negative values.

RAI is usually used to compare the deviation in precipitation in different regions.

\subsubsection{Identification of Contributing Determinants for Agricultural Production}

Irrigation facilities and soil moisture conditions are the critical determinants for agricultural production. Suppose there are no irrigation facilities at the field level; in that case, crop production mainly depends upon the soil moisture condition and available rainfall on that particular crop period, excluding other enabling environments like an improved seed, fertilizer, tools, and techniques. If the agricultural area is rainfed, the meteorological drought index could relate to agricultural production.

\section{Results and Discussion}

\subsection{Observed Rainfall Distribution}

Figure 1 shows the average annual precipitation across different provinces, and Figure 3 shows the temporal distribution of average monthly precipitation for 41 years from 1975 to 2015. Gandaki province's central region receives the maximum amount ( $>3500 \mathrm{~mm})$ of the annual rainfall (Figure 1). In contrast, the northwest of the same province receives the minimum $(<200 \mathrm{~mm})$ amount of yearly rainfall. On average, Karnali province receives rainfall in the range of 200-1600 mm, whereas Bagmati province and Province 1 receive the annual rainfall in a range of $600-3500 \mathrm{~mm}$. The monthly rainfall is more than $200 \mathrm{~mm}$ from June to September, also a rainy/monsoon season (Figure 3). Approximately $80 \%$ of the total rainfall is received in these four months only. The remaining eight months (October to May) get monthly rainfall of less than $200 \mathrm{~mm}$. It clearly shows July experiences the maximum rainfall $(602 \mathrm{~mm})$ followed by August $(585 \mathrm{~mm})$, June $(452 \mathrm{~mm})$, and September (394 $\mathrm{mm}$ ). High temporal heterogeneous distribution of the rainfall reflects the possibility of extreme events such as drought and flood, which need to be addressed for proper watershed management.

\subsection{SPI Using Observed Data}

\subsubsection{Temporal Analysis}

On the one-month time scale, SPI-1 is plotted for 41 years (1975-2015) for two representative meteorological stations, station 101 and station 308, to represent the drought state at the point level. These two stations were chosen as representative because they 
receive relatively less annual and monsoon rainfall than other stations. Figure 4 shows SPI-1 values, temporal distribution, two months of January and August, and cumulative distribution function (CDF) at Station 101. The station is located in the far western region in Sudurpaschim province. Similarly, Figure 5 shows the same for station 308, located in the mid-western region at Karnali province. The figures show that 1984, 1997, and 2012 experienced severe drought at station 101, whereas station 308 experienced severe drought in 2008 and 2014. On average, both the stations experienced near-normal drought $(-0.99>$ SPI $<0.99)$ throughout the study period, however, both the intensity and frequency were intense in the later years.
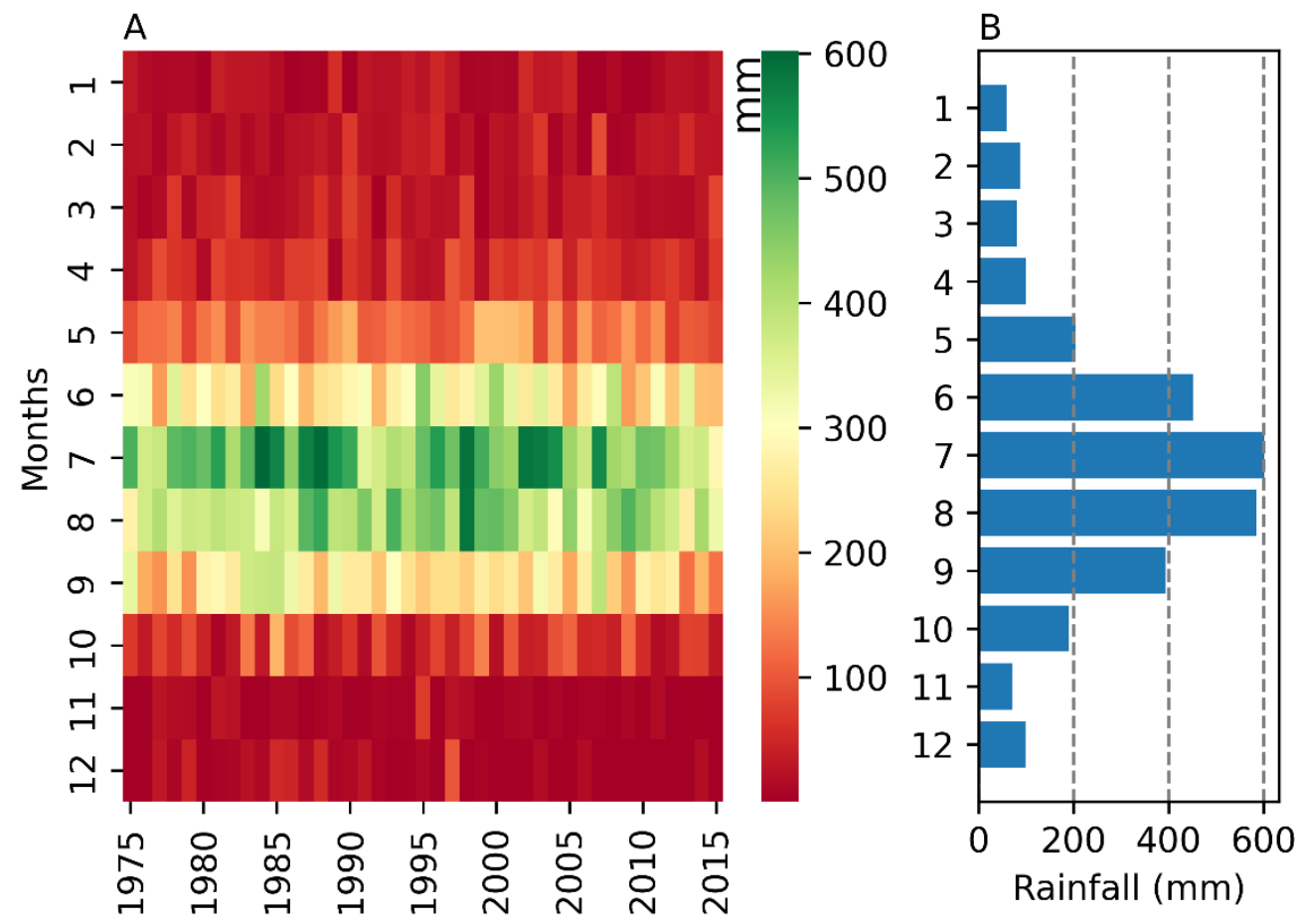

Figure 3. (A) Heat map of cumulative monthly precipitation data over the period of 1975-2015, where monthly rainfall values $(\mathrm{mm})$ are represented by colors, and (B) average monthly distribution of rainfall (mm) for 1975-2015 over Nepal.

The monthly distribution of the one-month drought shows the lesser intensity of SPI wet values and higher intensity of SPI drought values in January. The number of wet days is higher during August. The high number of wet days in August might be because of the monsoon season (June-September). Monthly distribution of the drought events at station 101 shows high frequency in January. The station experienced continuous drought from 2006 to 2011 in January. The same station experienced drought from 2001 to 2006, even in August. Some years (1979, 1997, 2001, 2009, and 2011), even in August, experienced moderate to severe drought $(+1<$ SPI $<+2)$ at station 308 , with the number of drought events getting more frequent beyond 2000. Simultaneously, we found that the number and intensity of moderate to severe droughts are high during January. As a result, an increase in the number and intensity of droughts directly impact crop yield and other hazards, such as increased heat strokes.

The CDF for stations 101 and 308 is plotted for the wet (August) and dry (January) months. The probability value ranged from 0.07 to 0.94 against the variation of SPI values $(-1.45$ to +1.54$)$ in January at station 101 . Similarly, the probabilistic variation of CDF varied from 0.03 to 0.99 with the variation of SPI values of -1.92 to +2.32 in August at the same station. In January, the probability ranged from 0.12 to 0.92 against the SPI -1.17 to +1.4 . Similarly, the probability ranged from 0.02 to +1.00 for the SPI $-1.97+2.69$ in August. The other stations also show a similar nature in probability distribution compared to the 
SPI values. The CDF distribution of both dry and wet months shows that the SPI events were fitted entirely with the normal distribution.
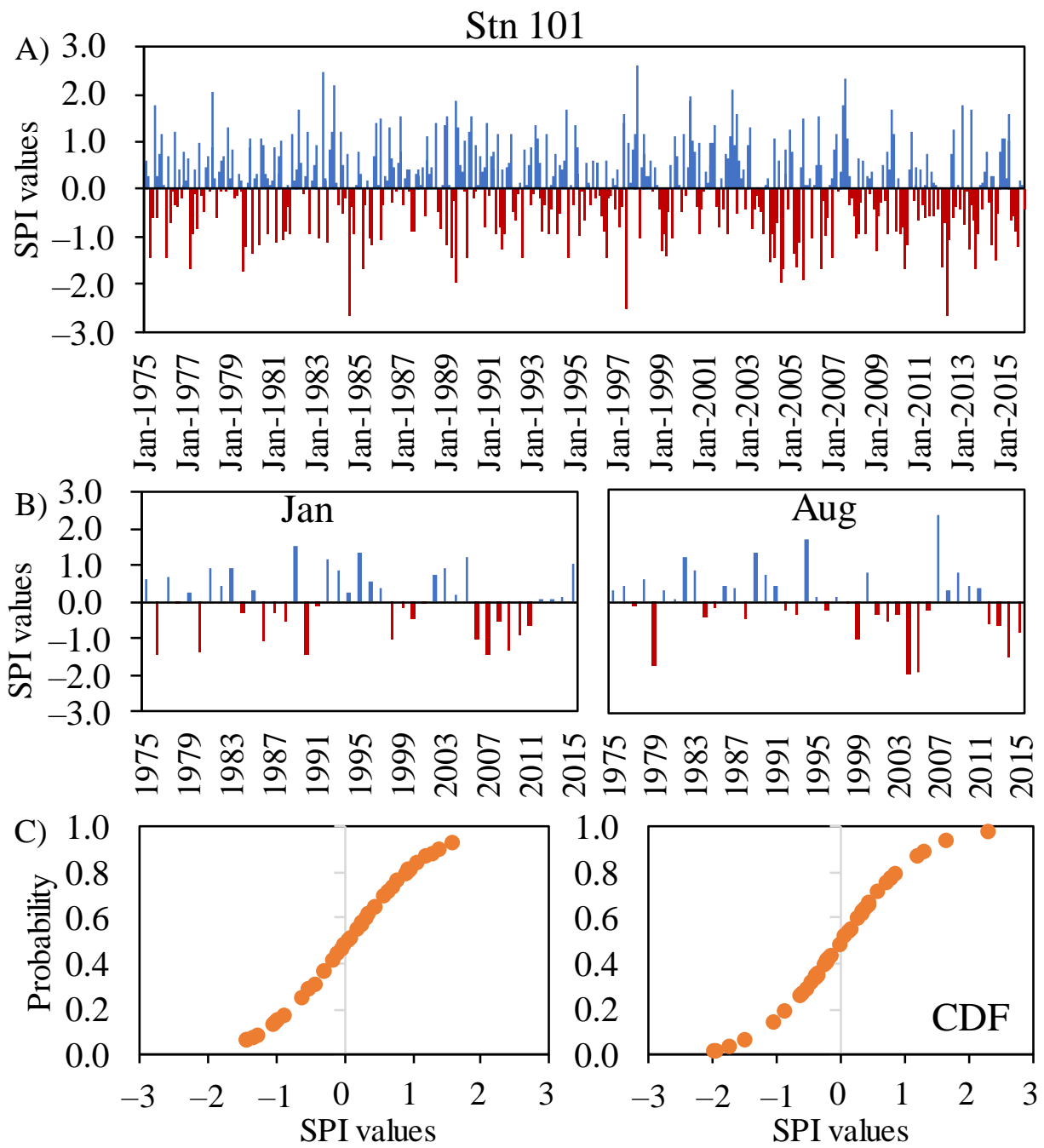

Figure 4. Standardized precipitation index (SPI-1) values at station 101 for January and August. Panel (A) shows the temporal variation of SPI values over 1975-2015, panel (B) shows the same for January and August, and panel (C) shows the cumulative density function (CDF) for January and August.

The northwest region has low precipitation compared to the mid-western and eastern regions, which have moderate and high precipitation. The temporal distribution of various precipitation stations revealed the SPI values in the northwest region is in drought between 2000 and 2010, with increased severity of drought in 2002. Similarly, there has been no severe drought in the eastern region for the past 41 years, but the onset and termination of the drought are frequent, i.e., in cyclic order. The mid-western region has less drought time compared to the other areas. We found that the annual average precipitation in the western region is low, and it is moderately high in the eastern region. For most of the monsoon period, 1975-1985, the recorded precipitation is unavailable in the eastern region, which might be the reason for the drought for the first ten years. For other years, severe drought is not observed in the eastern and western regions. This fact reveals that these areas have the possibility of rain-fed activities such as agriculture and hydropower production (where the head is available). The northwest is under drought but not severe, which might be the consequence of arctic oscillation and persistent warming of the Indian Ocean [57]. The drought severity is high in the country after 2000, which is in agreement with the result 
obtained by Hamal et al. [58]. In a nutshell, drought in the country will significantly affect the environment, economy, and social livelihoods [59].
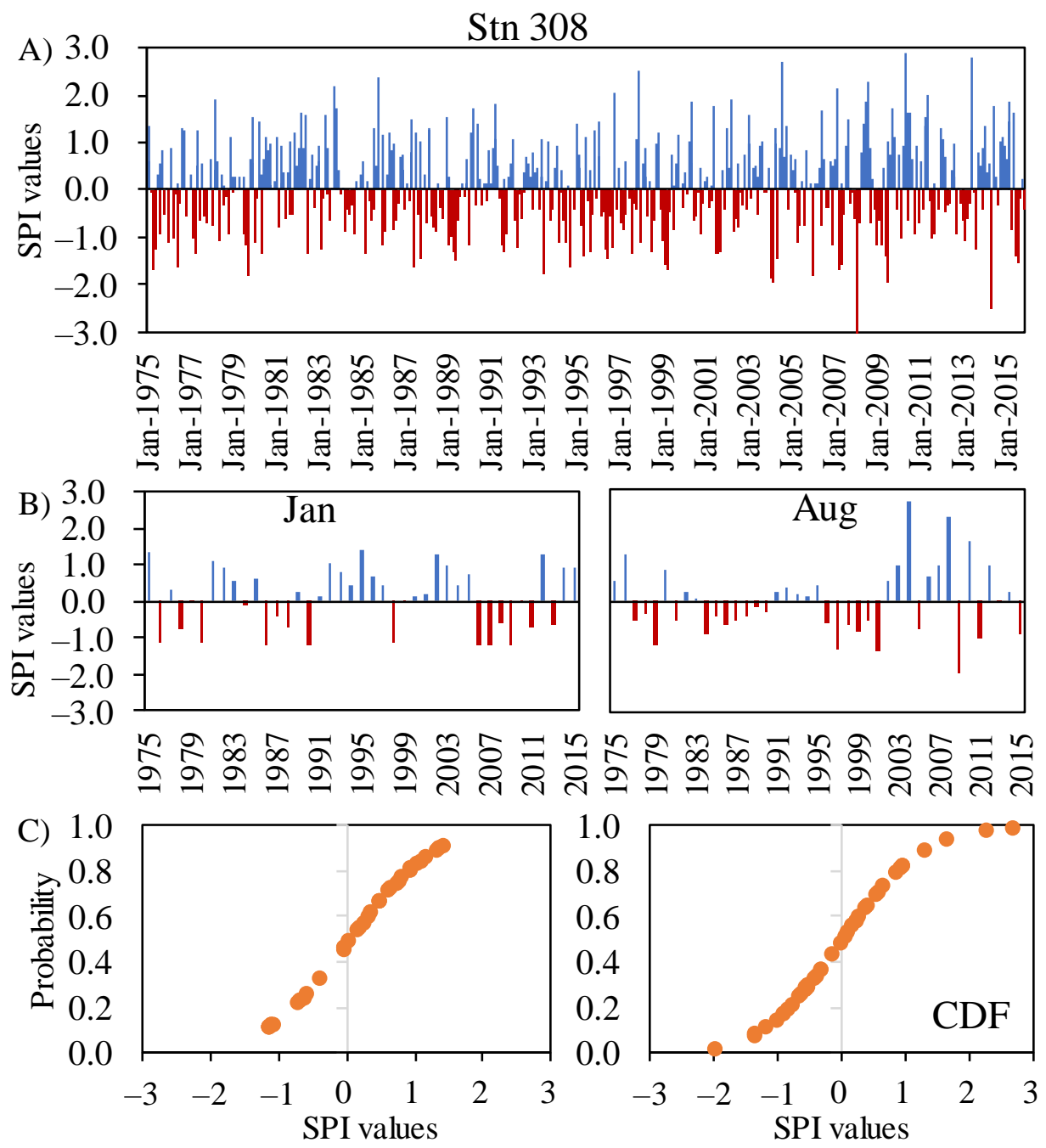

Figure 5. Standardized precipitation index (SPI-1) values at station 308 for January and August. Panel (A) shows the temporal variation of SPI values over 1975-2015, panel (B) shows the same for January and August, and panel (C) shows the cumulative density function (CDF) for January and August.

\subsubsection{Temporal Fluctuation of SPI Events}

The temporal fluctuation of SPI values for stations 101 and 308 is shown in Figure 6. For most of the years, there is severe drought (i.e., SPI > -2 ) in all the SPI evolutions in the considered meteorological stations. However, both the stations experienced extreme drought (SPI < -2) after 2005 in SPI-1, SPI-3, and SPI-6 time evolutions. For SPI-6, extreme drought was observed in 1989 and 1994 at both stations. In contrast, results of the SPI-12 show no extreme drought at either station but a wet year after 2005.

\subsubsection{Spatial Analysis}

Figure 7 shows the spatial distribution of the one-month SPI in half-decadal time (5-year) scales. We observed from normal drought to moderate wetness in all periods. In particular, normal droughts were detected in more expansive areas in 2005, 2010, and 2015. We found that the eastern region (Province 1) and northwest region (Karnali and Sudurpaschim province) have normal drought, whereas the remaining area experienced normal wet in 2005. The spatial distribution of the normal drought was extended to Madhesh province and Bagmati province in the years 2010 and 2015. 

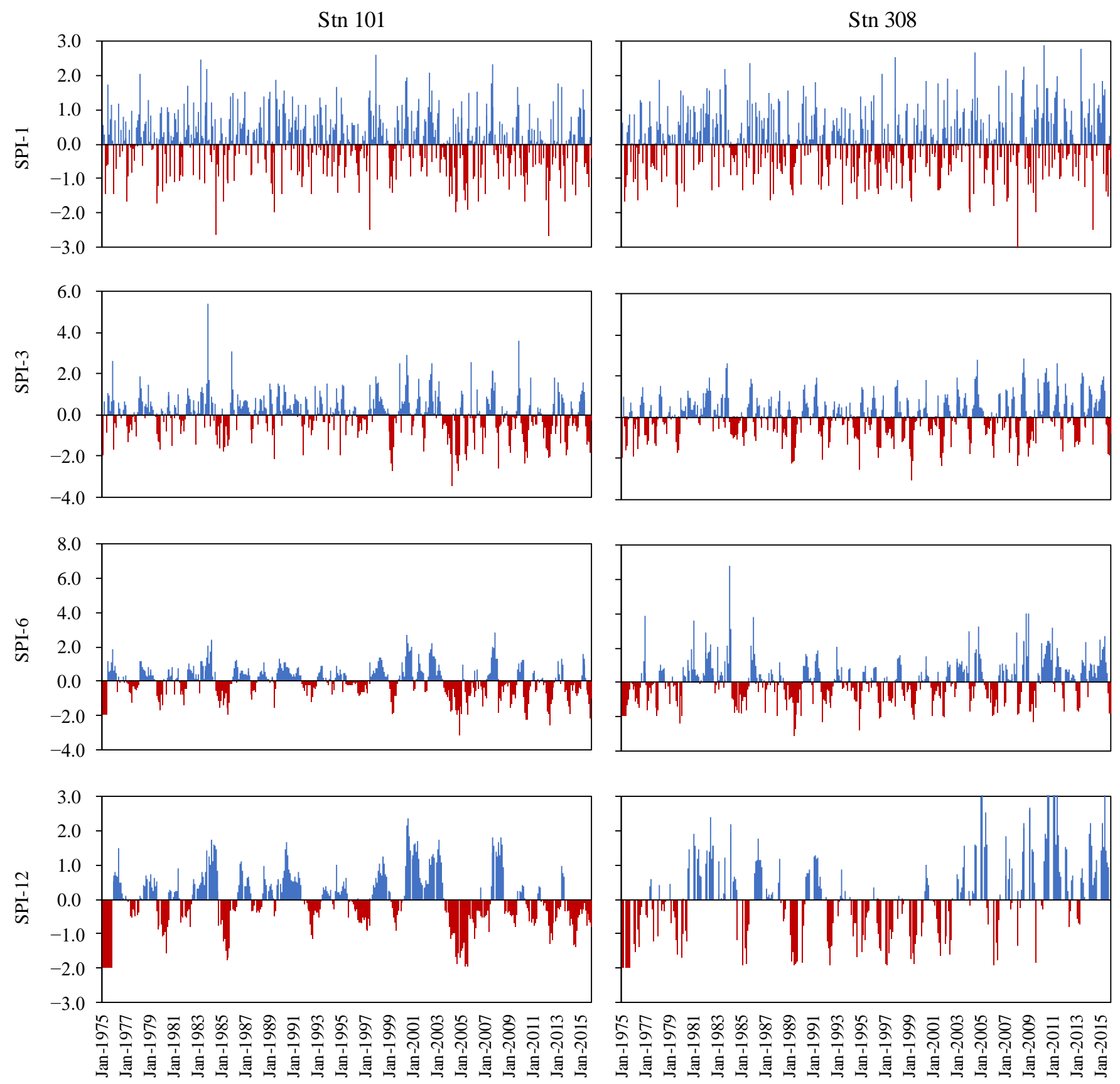

Figure 6. Temporal evolution of SPI-1, SPI-3, SPI-6, and SPI-12 at stations 101 and 308.

The annual spatial distribution is extended from normal wet in 1985 to extremely wet, with traces of extreme drought in 2014. The figure shows that the small traces of drought were prevalent until 2005, but after that, the severity of the drought changed from normal wet to normal drought in most regions. The eastern and northern regions were found to have a noticeable drought impact. The average annual SPI-1 revealed that none of the regions was impacted by moderate to extreme drought until 2015. The average yearly SPI-1 value ranged from +0.384 (2003) to -0.112 (2009). 


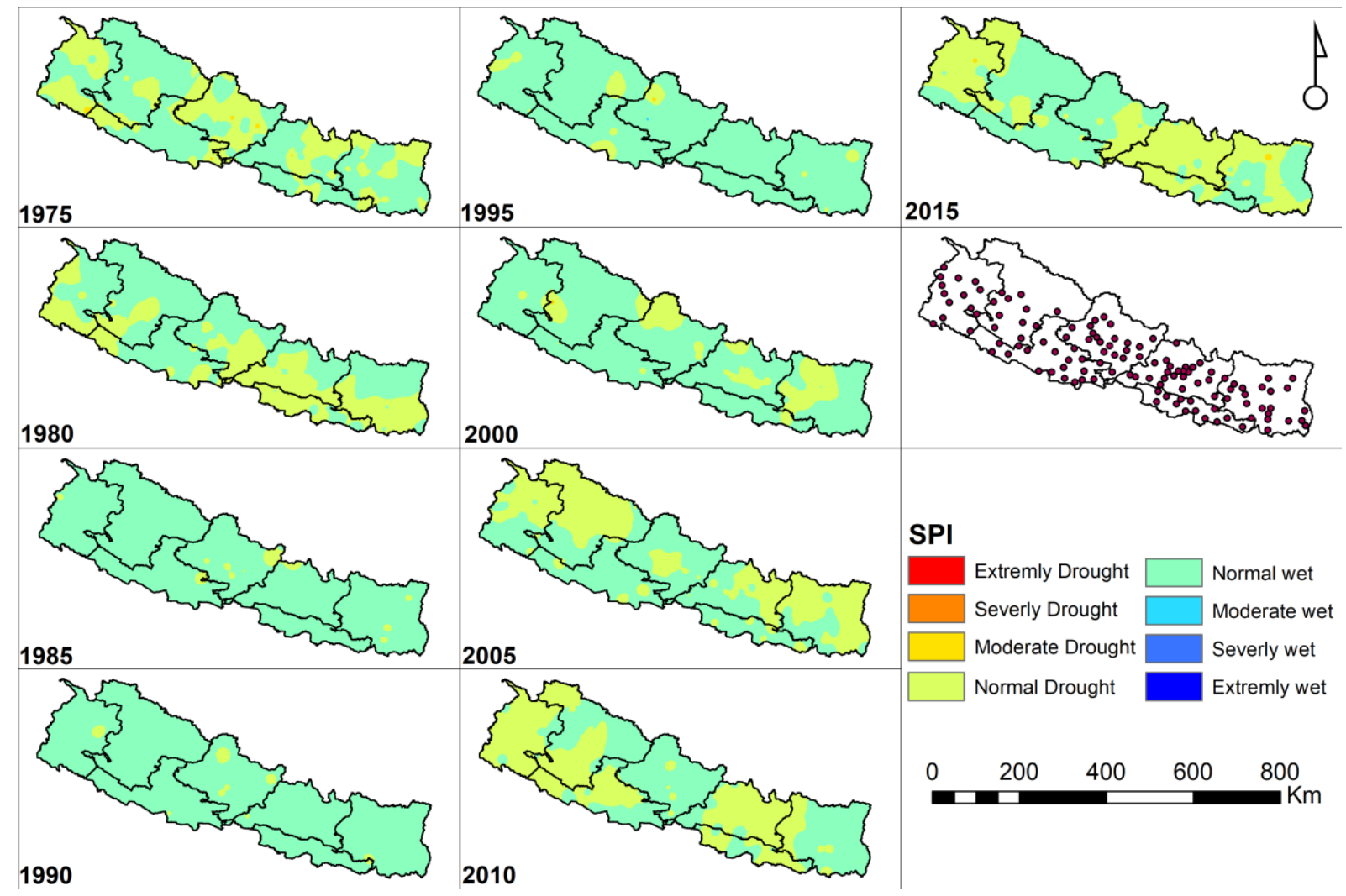

Figure 7. Standardized precipitation index (SPI) for different years at half-decade (5-year) intervals across Nepal.

The monthly spatial plots for different SPI time scales are shown in supplementary figures (Supplementary Materials, Figures S1-S4). The figures depict that the severity of drought increases as the SPI time scale increases. The central (Bagmati and Gandaki provinces) and eastern (Province 1) regions were found to have a higher degree of drought than other regions in all the SPI time scales. However, the average monthly distribution of SPI values ranged from +0.52 (July) to +0.02 (January). SPI spatial distribution showed that the northern regions were less vulnerable to drought compared to the central and eastern regions, which is equally represented by Cavus and Aksoy [60]. The result further stated that the degree of drought severity reduced with elevation. The monsoon season's unpredictable change might have resulted in the drought vulnerability in some monsoon years [61]. The spatial distribution of SPI drought showed the increasing drought trend in the country's far western region beyond 2005. A similar trend was observed in the research conducted by Khatiwada and Pandey [59] in the Karnali River Basin (Karnali Province) in the far west. The country's central region also received normal drought beyond 2005, as observed by Dahal et al. [46].

\subsubsection{SPI Events}

Figure 8 shows the monthly SPI- 1 events for $1975-2015$ on a decadal time scale. The figure reveals the variation in SPI- 1 values in the different months at different years. The SPI-1 variation was found to vary from severe drought $(-2)$ to severe wet $(+2)$. The drought was more pronounced in September and October than the other months in the later years. By analyzing the intra-annual variation of the mean SPI-1 values, we find that 1975-2015 had near normal and moderate ( $1 \geq$ SPI- $1 \leq 1.5)$ wet years. The years $1985,1986,1988$, and 1997 were moderate wet years with average SPI- 1 values varying from +1.31 to +1.91 . The other years were near-normal years with SPI- 1 values ranging from +0.08 to +0.91 . 


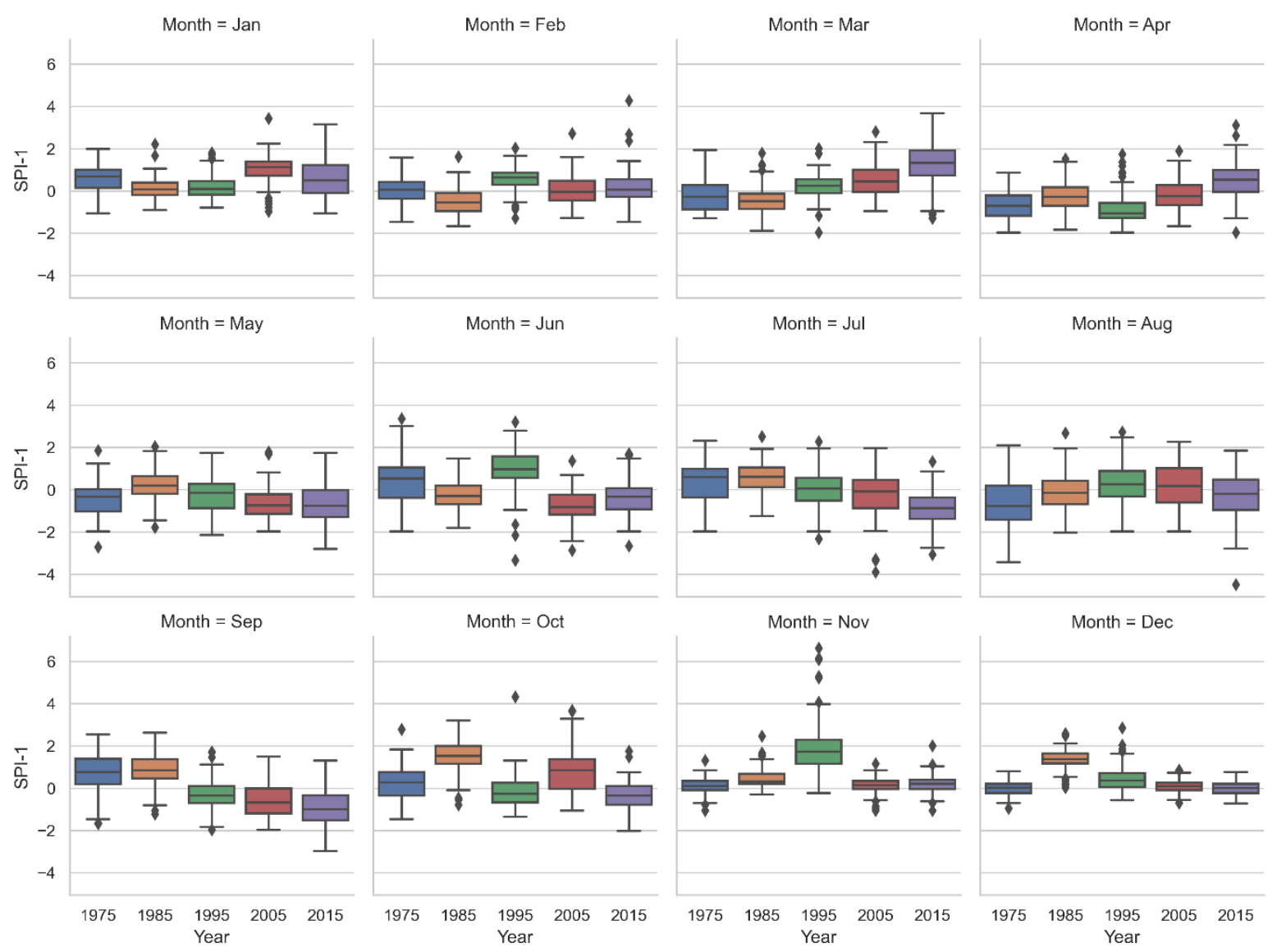

Figure 8. Boxplot representing the variation of SPI-1 events throughout 1975-2015 for Nepal.

Most of the mean SPI-1 values for the annual times vary between 0 and 1 . The minimum and maximum SPI-1 values were -0.86 (near normal) and +2.52 (extreme wet). The near-normal droughts have been observed periodically since the 1990s (1993, 1995, 2002, 2004, 2011, 2013), implying the recurrence of drought events in the future. In contrast, the years with extreme wet events are fewer (1985, 1986, 1988, 1989, 1995, and 1997). The number of extreme wet events has not been observed since 1997, which implies reduced precipitation. The year 1997 was reported to be an extremely wet year, whereas, on average, none of the years was reported to have an extremely dry year. Therefore, most of the historical years were observed to have near-normal years.

\subsection{RAI Using Observed Data}

\subsubsection{Temporal Analysis}

Temporal analysis of the rainfall anomaly index (RAI) over Nepal was carried out for 41 years (1975-2015), as shown in Figure 9, portraying the drought and rainy years. It can visualize the periods where drought and rainfall events occur throughout the temporal period. Most of the year, RAI is positive $(>0)$, whereas some years experience a dry year before 2005. Most of the years after 2005 experienced dry years, whereas only two years (2008 and 2011) were humid. The positive values observed in Figure 9 represent rainy or wet years, and the negative values represent the dry years with different degrees of intensity. The occurrence of 23 years with a positive RAI, varying from extremely wet to humid, and 18 years with a negative RAI, ranging between very dry and dry, was observed. In other words, the drought years and rainy years are comparatively equal in numbers for the 41-year period. On analyzing the 41 years, drought years lasted for three years (1975-1977) before 2005, whereas the drought year increased to a maximum of 4 years in the later period of analysis, i.e., 2012-2015. However, none of the years had an extremely 
dry year, i.e., RAI > -4. Further, the state of dryness increased with time, which stimulates water scarcity after 2005.

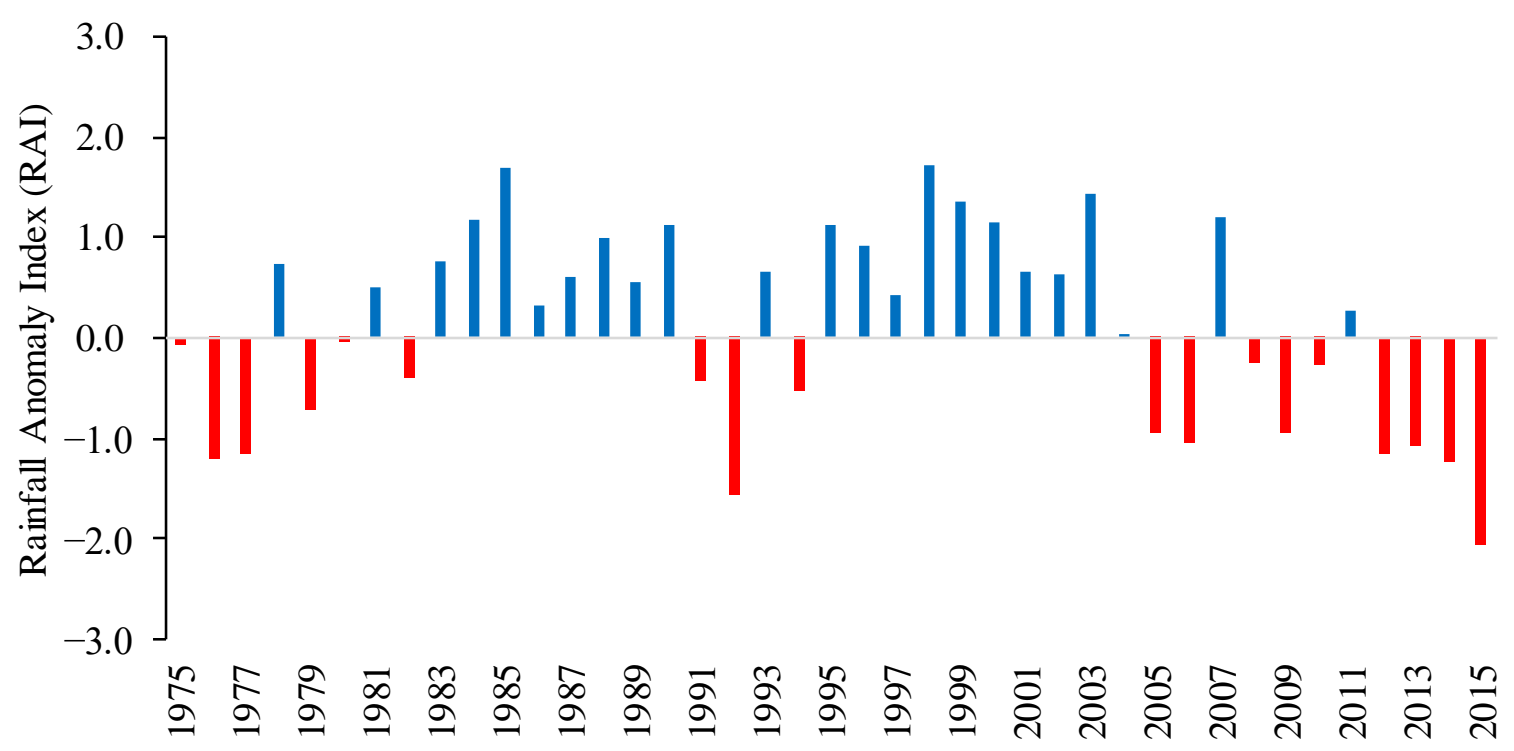

Figure 9. Annual rainfall anomaly index (RAI) for Nepal.

The monthly distribution of RAI based on the rainy (1985 and 2003) and drought (1993 and 2015) years is shown in Figure 10. June to September is treated as rainy months, and the remaining months are exhibited as drought months for both drought and rainy years. The monthly distribution of RAI shows the month of June and September experienced drought months compared to the remaining months. For most of the drought month for both drought and rainy years, dryness intensity does not exceed the "very dry" condition. For example, the driest years in the historical series (Figure 10) presented precipitation above average only in July and August for 1993 and 2015, whereas it continued for June and September for 1993. However, the drought year 2015 experienced dryness in June and September (intensity label as dry). In this light, it is possible to infer that there are months when RAI tends to be negative in very dry years, even in the rainy season.

\subsubsection{Spatial Analysis}

The spatial distribution of RAI over the country in five years for the 41 years is shown in Figure 11. For 1985-2000, RAI intensity shows small traces of dryness in the central and western parts of the country. Beyond 2000, the intensity has shifted to dry compared to 1985-2000, with the eastern region more susceptible to intense dryness, i.e., extremely dry. From 1975 to 1980, the intensity of RAI had a mixed nature, partially dry and humid. This might be because some stations operated late or could not record the rainfall data correctly during the early period of installation. The temporal distribution of RAI showed a similar trend of increasing drought after 2005 as indicated by SPI. However, the spatial distribution showed that the magnitude of the drought severity posed by RAI is high compared to those offered by SPI. The result further revealed that the eastern region had more pronounced drought compared to the country's western region.

\subsection{Drought Characteristics: Severity, Frequency, and Duration of Drought Events}

The frequency of extreme drought events (SPI-1 $<-1.5)$ is observed for different temporal scales (Figure 12A,B). Figures show the number of extreme drought events in the annual (blue line) and decadal (green dots) time scales. Here, the number of events is a sum of the events in each month. In the monthly time scale for 1985-2015, the maximum number of SPI-1 values (<-1.5) was found in July (235), whereas no such events were witnessed during November and December. Similarly, the inter-annual variation of the number of 
extreme drought events shows the rising tendency of such events in the last few years. During the last five years (2011-2015), the total number of events has increased from 243 in 2006-2010 to 441. The total number of drought events are 183 (1985-1990), 231 (1991-1995), 175 (1996-2000), and 212 (2001-2005), which implies an increasing nature of the number of extreme events. The monthly and seasonal variations for different decades-1985-1995, 1996-2005, 2006-2015 are also analyzed. The analysis shows that the number of events is higher than in earlier decades. Many such events are observed from May to September, implying the shifting of rainy days exacerbated by the changing climate at regional and local levels.

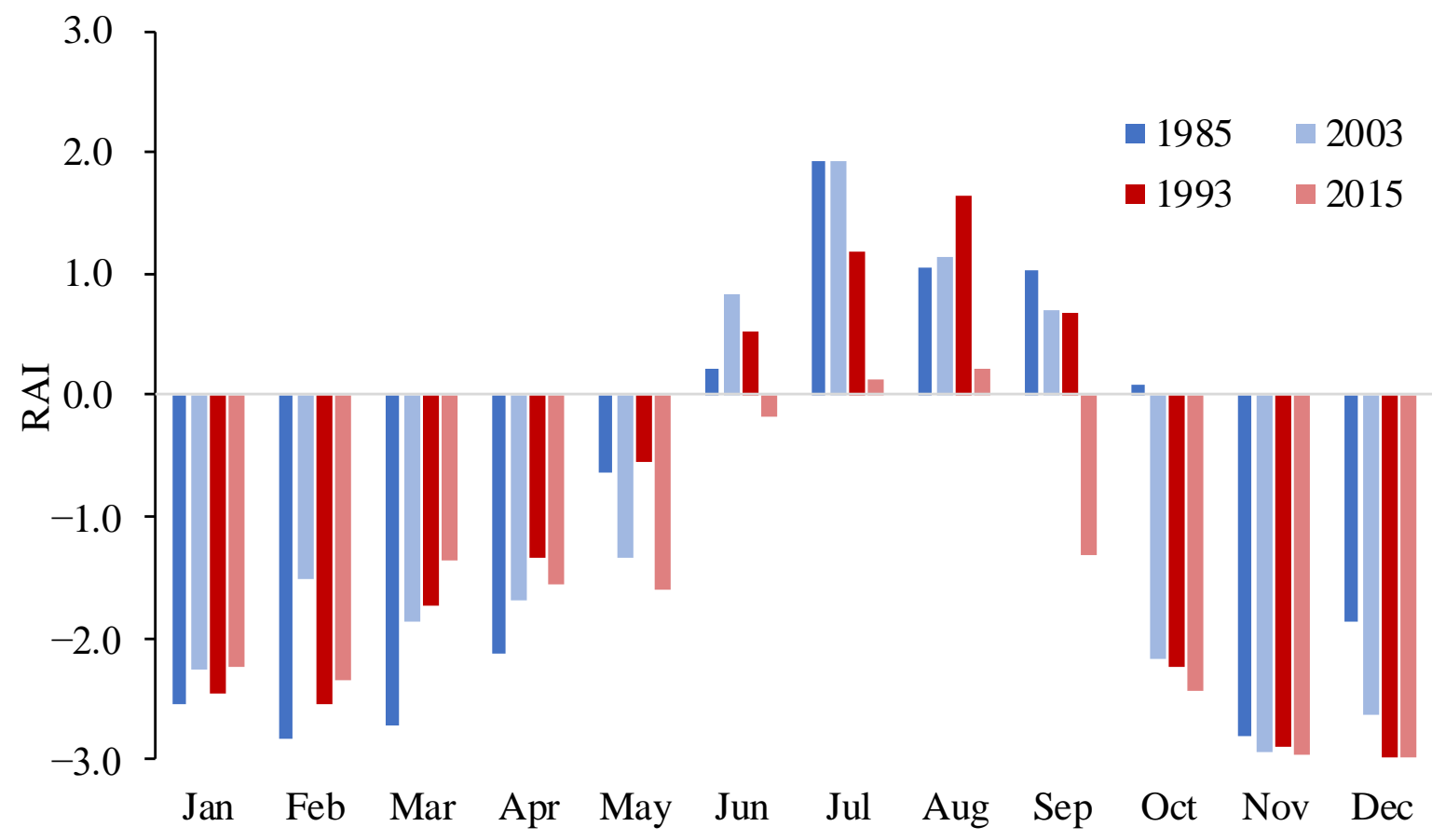

Figure 10. Monthly distribution of rainfall anomaly index (RAI) for rainy (1985 and 2003) and drought (1993 and 2015) years for Nepal.

In contrast, during April, the number of extreme events was higher during the 1985-1995 decade as some parts of the country exhibited less rainfall in 1989. The seasonal dispersion of the extreme drought events showed a similar tendency. The number of drought events increased by 2.28 times in 2006-2015 compared to 1996-2005 during JJAS months, whereas the annual events multiplied by 1.77 during the same period. The inclination of drought events in the later decades (or later years) signifies the risk of drier days.

The drought characteristics, frequency, and duration of SPI events were analyzed (Figure 12). The number of drought events is found to increase in both annual and decadal periods. The number of decadal drought events shows the increasing rate of drought events during the 1990s, which started reducing during 1990-2000 and again began to increase in 2000-2010. The number of drought events in the first five years of the 2010-2020 decade is more than 50, close to the number of drought events in 2000-2010. The increase in the number of warm years and decrease in the number of wet days might be the potential cause for the rise in the number of drought events in later decades. The maximum number of annual and decadal SPI-1 drought events less than -1.5 in the study region for the period 1975-2015 are 150 and 500, respectively. Similarly, the annual and decadal mean SPI-1 events $(<-1.5)$ are 42.17 and 6.14 events per year, respectively. 

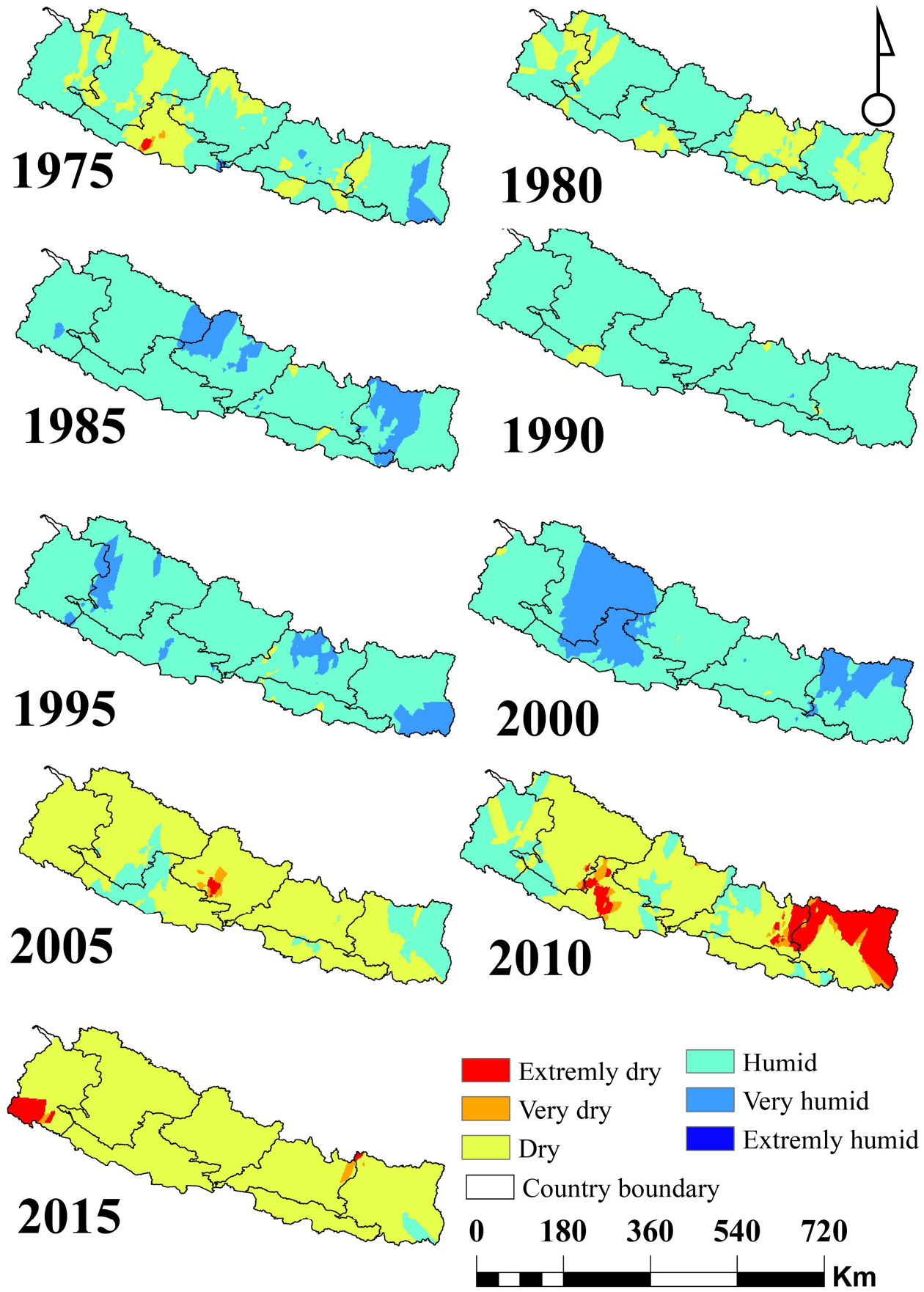

Figure 11. Spatial distribution of annual rainfall anomaly index (RAI) across Nepal.

\subsection{Impact of Drought on Crop Yield}

\subsubsection{Observed Crop Data}

Figure 13 shows the paddy crop's temporal distribution at selected districts in each province and the average paddy yield in seven provinces. Wesee that the paddy yield started to drop after 2005, which might be due to various factors such as rainfall deficit, lack of fertilizers, lack of cultivable land for crop yield, and improper land management practices. In contrast, the paddy yield's temporal distributionincreased in selected districts of Gandaki province and Lumbini. In addition, the paddy yield was reduced to $1.9 \mathrm{Mt} / \mathrm{Ha}$ in 2010 2.2 Mt/Ha in 2004 at Sankhuwasbha district in Province 1. Similarly, the yield was reduced to 2.1 Mt/Ha from 2.8 Mt/Ha at Siraha district in Madhesh. 

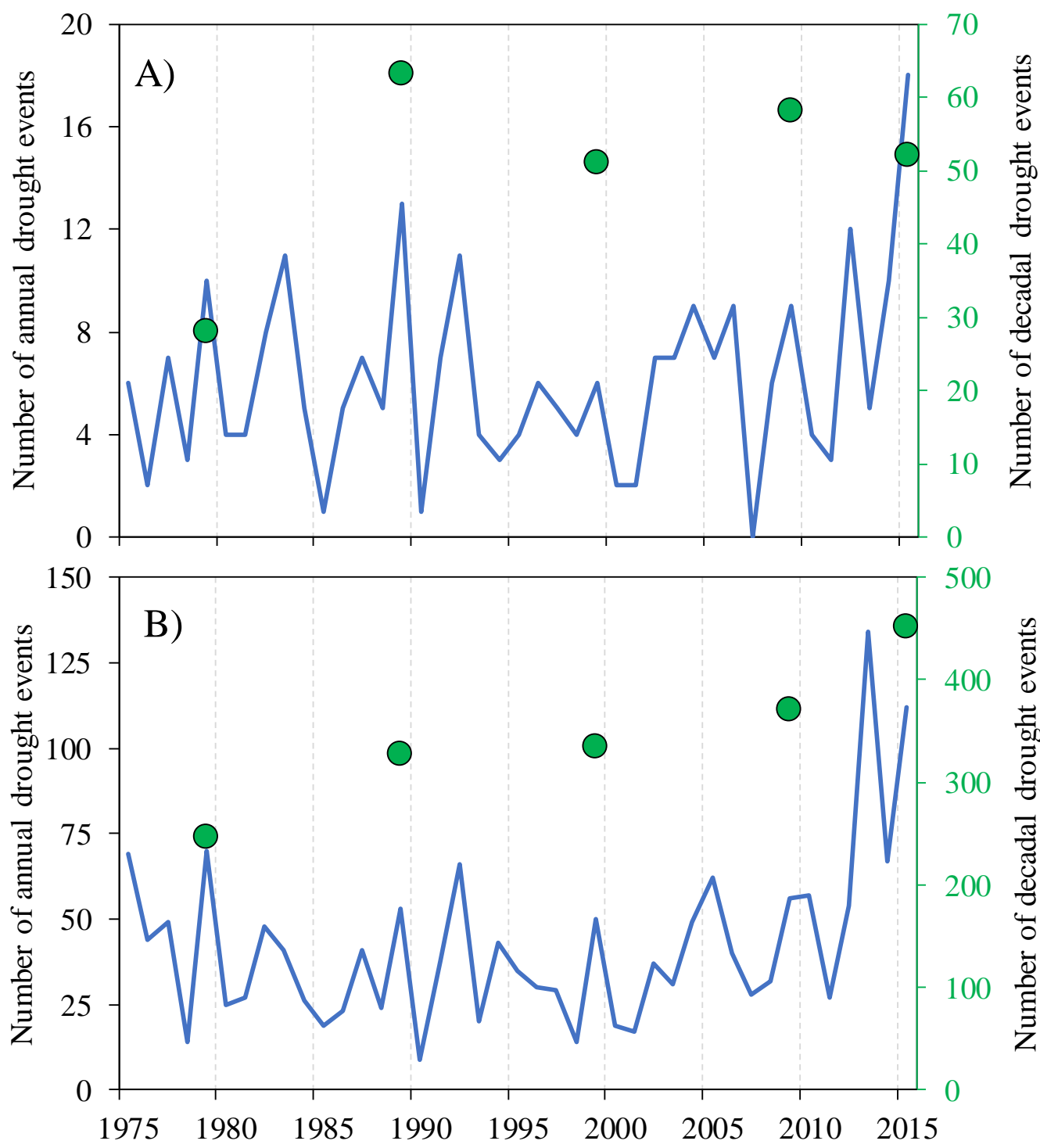

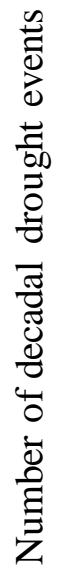

Figure 12. The number of annual SPI-1 drought events is expressed in (A) SPI values less than -2.0 and (B) SPI-1 values less than -1.5 . The blue line shows the yearly events, and the green dots show the decadal time-lapse instances.

In contrast, the Kaski district in Gandaki province and the Rupandehi district in Lumbini province were found to have increased paddy yield. The paddy yield rose to $2.9 \mathrm{Mt} / \mathrm{Ha}$ in 2009 compared to the paddy yield of $2.7 \mathrm{Mt} / \mathrm{Ha}$ in 2004 at Kaski district. A similar increment trend was observed in the Rupandehi district from 2.4 Mt/Ha in 2004 to 3.9 Mt/Ha in 2010. The progressive yield of paddy might be the irrigation services available in these districts. The paddy yield increased after 2000 from $1.9 \mathrm{Mt} / \mathrm{Ha}$ (1981) to $2.6 \mathrm{Mt} / \mathrm{Ha}$ (2011) in Province 1, whereas Madhesh yielded the same crop of 3.4 Mt/Ha in 2011. The lowest paddy yields were observed in Karnali province (2.4 Mt/Ha) and Sudurpaschim province (2.3 Mt/Ha) in 2011 compared to the paddy yields of $1.6 \mathrm{Mt} / \mathrm{Ha}$ in 1980 in Karnali province and $1.3 \mathrm{Mt} / \mathrm{Ha}$ in Sudurpaschim province. In Karnali province, the reduction in paddy yield might be because of a reduction in rainfall.

\subsubsection{Impact on Crop Production}

The annual crop production for major crops in selected districts of the country is shown in Figure 14 and Supplementary Materials, Figure S5. The districts are so selected that they represent the entire country. The temporal distribution of crop yield shows a reduced trend 
after 2007 for rice, maize, millet, and barley. During 1990-2000, rice production was reduced in the Bhaktapur district, attenuated by reduced rainfall and increasing built-up area. A rising crop production (yield) trend for major crops is observed with some noticeable spikes. An elevated crop yield is due to multiple factors, including improved seeds, fertilizers, and agricultural equipment. The establishment of irrigation facilities (overland or sprinkler/drip) in recent times helps farmers combat the negative consequences of climate anomalies, particularly drought. A negative spike in rice production in Bhaktapur (Bagmati province) was observed in 2009 during the latter part of the analysis period. 2009 is characterized by a moderate drought from both the drought indices. Similarly, Surkhet and Dolpa (Karnali province) significantly reduced rice production in 2010. They are located in the western region, when 2010 was characterized as a drought year in the western parts of Nepal. In particular, Surkhet had reduced the production of barley, maize, and millet in 2010.
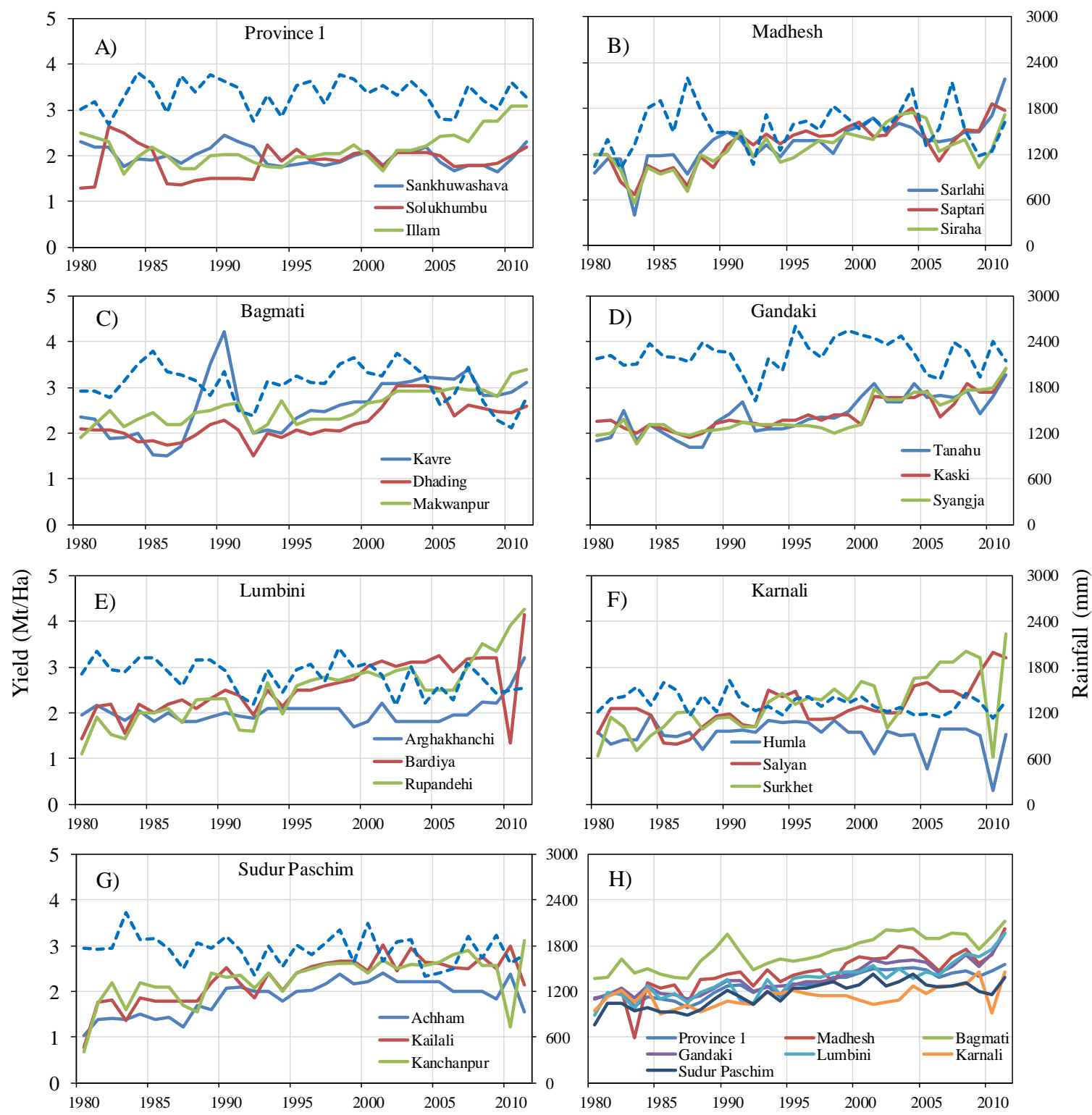

Figure 13. Yearly evolution of paddy yield at different districts of each province (A-G) along with rainfall amount and average crop yield for each provinces $(\mathbf{H})$. The solid lines show the paddy yield and the dotted line shows the annual rainfall distribution. 

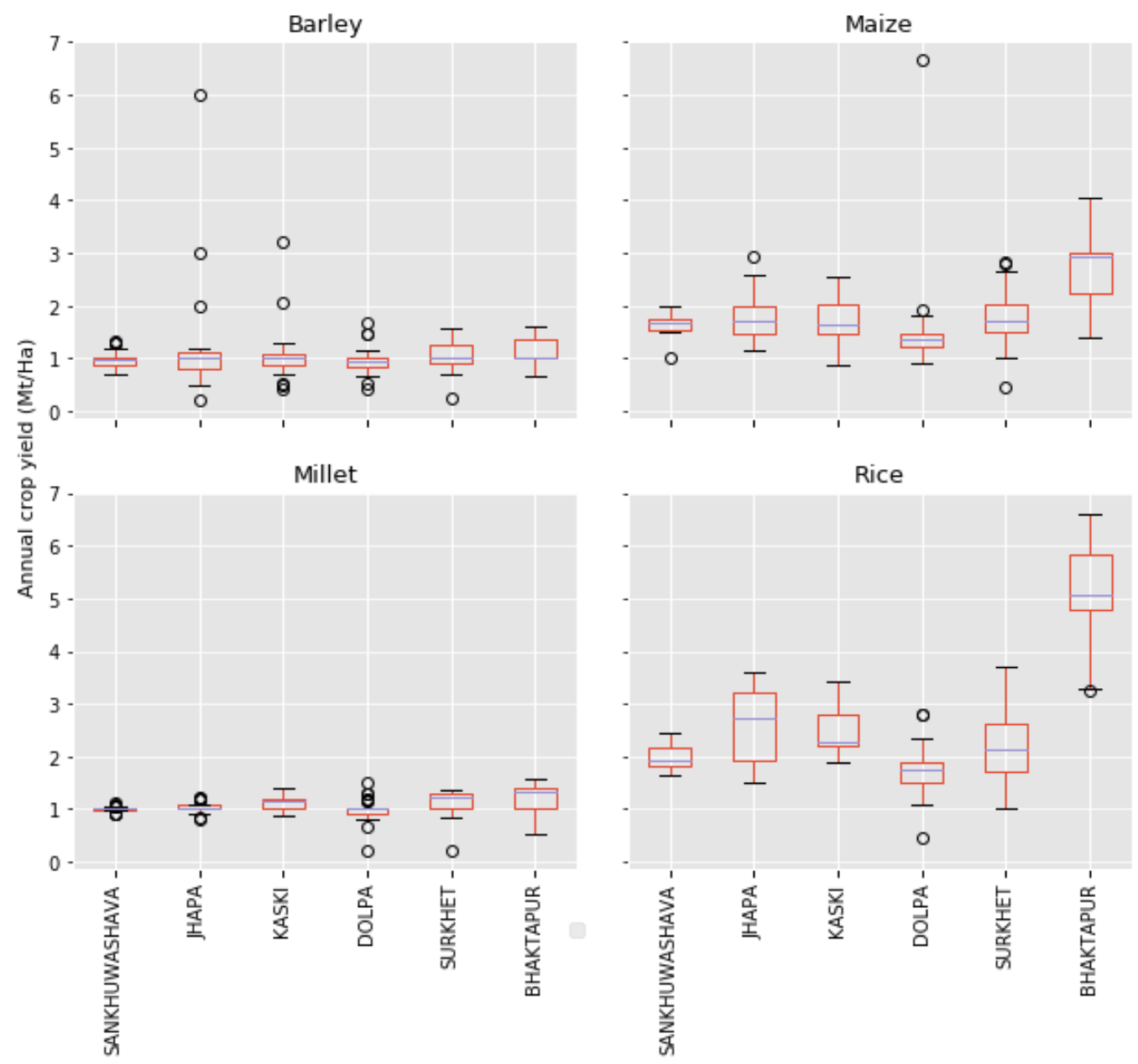

Figure 14. Annual crop yield in different districts of the country. Districts are chosen so that they cover the entire country from east to west and depict topographical variation.

Interestingly, reduced production of rice was compensated for by an elevated maize production in Dolpa in 2010. The result suggests the switching of the crop from rice to maize in 2010. Short growing seasons and low temperatures limit crop growth in high mountains like Dolpa [43]. Maize, barley, and millet are grown at higher elevations, limiting the crop in a year. They are mainly rain-fed, and irrigation facilities are limited. Cold-tolerant rice is grown in such areas; for instance, Jumli Marshi (traditional rice varieties) is produced on the mountain slopes of Jumla (2830 $\mathrm{m}$ asl), the highest altitude rice-growing location in the world [62]. In mid-hills like Surkhet, crop cultivation is practised in both summer and winter. Thus, crop-shifting in mid-hills is not significantly apparent as it is in high mountain districts.

Figure 15 shows the temporal distribution of considered drought indices (SPI-1 and RAI) over the studied period in different districts of each province. The left top is Province 1 , and the left bottom is Sudurpaschim province. An apparent variation of SPI- 1 and the crop yield is observed for the considered districts, whereas a distinct variation with the RAI could not be observed. For example, Dhading district in Bagmati province increased the paddy yield during 1991-2006 (wetter side), whereas a reduction was observed during 2007-2011 (drier side). A similar trend is observed for other districts and crops across the country. Lower regions of the country are flatter in topography (like Sarlahi), where rice is cultivated two times a year and other crops have multiple harvests. They are the country's food granary, and irrigation facilities are readily available compared to other physiographical regions of Nepal [44]. Throughout the study period, a steady rise in crop production could be found in Jhapa. A considerable spike could be found in barley 
production in Jhapa in the year 1998. Two noticeable spikes are observed in 1995 and 2006. It is challenging to find the causes behind these spikes because these are affected by multiple factors, including natural and human interventions. However, a clear indication of a regular or routine break could be seen during a drought period. A precise analysis on an event basis at a different location demands digging/dissecting the underlying causes. Our study, though general, might be useful for sufficient water resources and irrigation facilities management. Considering the likely drought effects, a proper selection of crops and their rotations can be assessed for different locations at different times. Inter-basin water transfer is another viable option for managing water balance between deficit and surplus areas. A naturally occurring drought, if well understood, can be managed, and the negative consequences can be mitigated.
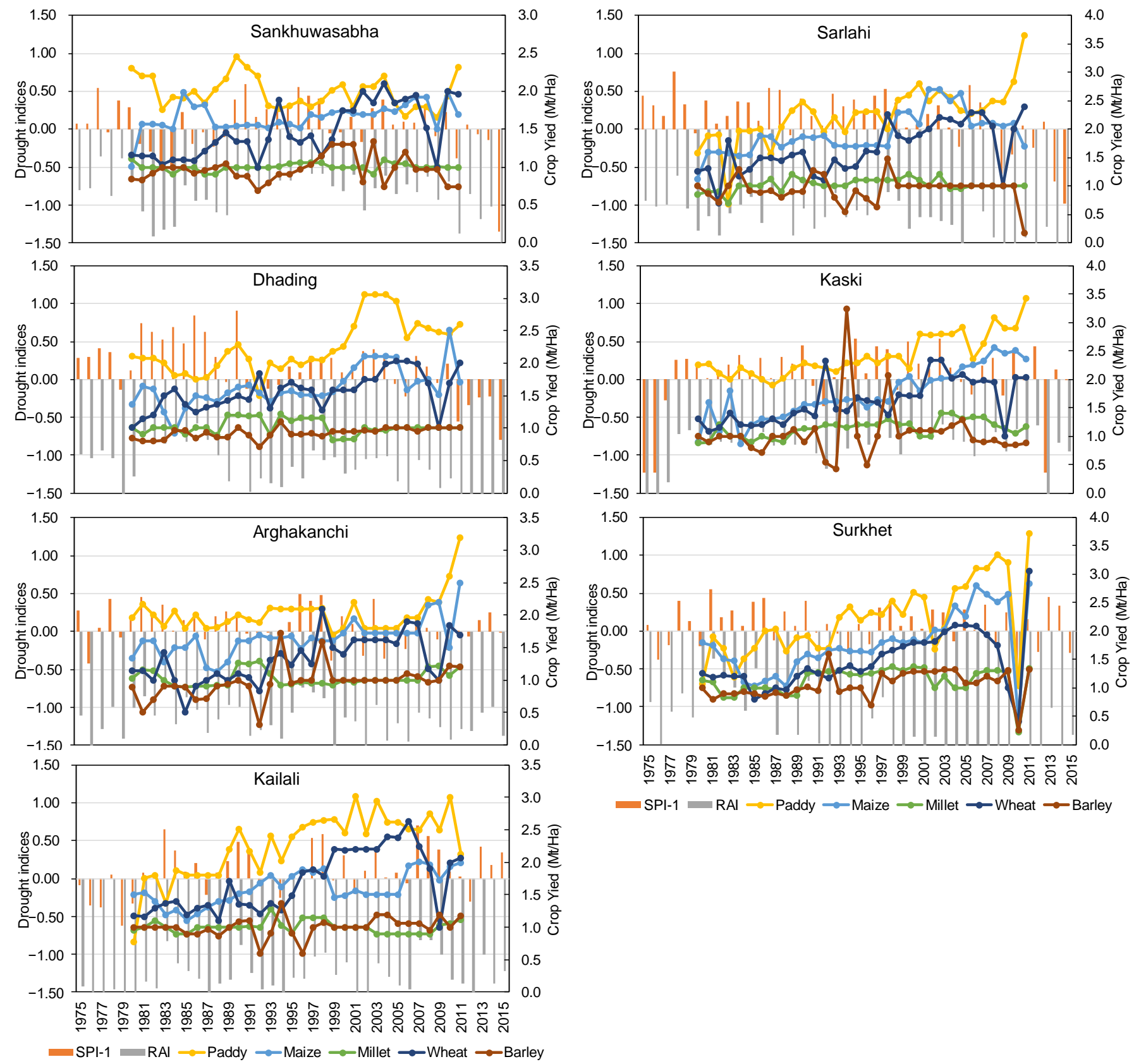

Figure 15. Temporal evolution of drought indices (SPI-1 and RAI) and crop yield for each province's selected districts in Nepal. 


\section{Conclusions}

This study used two drought indices, namely SPI and RAI, to map Nepal's metereological drought condition both temporally and spatially. Although SPI has been extensively applied for drought mapping, RAI has been less explored in earlier studies. Thus, this study used 41 years (1975-2015) of 124 station precipitation data distributed heterogeneously over Nepal to analyze both SPI and RAI. Analyzing all the meteorological stations, we found that the average annual SPI-1 value ranged from -0.20 for most of the year to +2.21 (1997) at station 101. Similarly, at station 308, the annual average SPI-1 value ranged from -0.20 to +2.31 . The temporal distribution of SPI shows the increasing tendency of drought events beyond 2009 for SPI-1, 2006 for SPI-3, and 2004 for SPI-6 and SPI-12. The temporal SPI result concluded that the drought situation has risen in Nepal after 2004, which might be the consequence of anthropogenic activities. The temporal distribution showed an increasing trend of drought in recent years. Hence, research on drought impacted by climate change seems necessary to project the future temporal drought. The spatial distribution of SPI showed that eastern regions are subjected to drought under different SPIs. The result from the observed rainfall exhibits the near-normal SPI conditions in most of the regions in Nepal. The result concludes that the spatial distribution of the drought is not very severe across the country. However, if the trend continues and a proper mitigation approach is not adopted, the situation might lean towards severity and may cause an impact on water resource management and associated fields. The spatial and temporal results of RAI showed a similar trend to SPI in the drought level. The wet months (June-September) show the positive RAI anomaly, whereas the dry months (October-May) show the negative RAI anomaly. The RAI spatial distribution showed the drier condition towards the eastern region, whereas the western region showed wetter conditions similar to those portrayed by SPI. Both SPI and RAI can equally explain the meteorological dryness/wetness. The variation in the crop yield had been observed through the variation of SPI events. With the increase in the wetter years, the crop yield increased in the Dhading district, wheras the crop yield reduction was found in the drier years. We finally conclude that the meteorological variation directly modulates the crop yield.

Supplementary Materials: The following supporting information can be downloaded at: https:/ /www.mdpi.com/article/10.3390/earth3010025/s1, Figure S1: Monthly distribution of SPI1values averaged over 1975-2015 across Nepal, Figure S2: Monthly distribution of SPI-3 values averaged over 1975-2015 across Nepal, Figure S3: Monthly distribution of SPI-6 values averaged over 1975-2015 across Nepal, Figure S4: Monthly distribution of SPI-12 values averaged over 1975-2015 across Nepal, Figure S5: Annual distribution of crop yields at different districts of Nepal over 1980-2011.

Author Contributions: Conceptualization, A.A. and M.M.; formal analysis, A.A.; methodology, A.A. and R.T.; resources, A.A.; software, A.A.; supervision, M.M. and B.R.T.; validation, A.A.; visualization, A.A., M.M., R.T. and B.R.T.; writing—original draft, A.A.; writing—review and editing, M.M., R.T. and B.R.T. All authors have read and agreed to the published version of the manuscript.

Funding: This research received no external funding.

Institutional Review Board Statement: Not applicable.

Informed Consent Statement: Not applicable.

Data Availability Statement: Not applicable.

Acknowledgments: The authors would like to express sincere gratitude towards the Department of Hydrology and Meteorology (DHM) and the Department of Agriculture for providing crop data, Nepal for providing the necessary data to complete this research work.

Conflicts of Interest: The authors declare no conflict of interest. 


\section{References}

1. Kundu, A.; Patel, N.R.; Denis, D.M.; Dutta, D. An estimation of hydrometeorological drought stress over the central part of India using geo-information technology. J. Indian Soc. Remote Sens. 2020, 48, 1-9. [CrossRef]

2. Allen, C.D.; Macalady, A.K.; Chenchouni, H.; Bachelet, D.; McDowell, N.; Vennetier, M.; Kitzberger, T.; Rigling, A.; Breshears, D.D.; Hogg, E.H.; et al. A global overview of drought and heat-induced tree mortality reveals emerging climate change risks for forests. For. Ecol. Manag. 2010, 259, 660-684. [CrossRef]

3. Gitlin, A.R.; Sthultz, C.M.; Bowker, M.A.; Stumpf, S.; Paxton, K.L.; Kennedy, K.; Muñoz, A.; Bailey, J.K.; Whitham, T.G. Mortality gradients within and among dominant plant populations as barometers of ecosystem change during extreme drought. Conserv. Biol. 2006, 20, 1477-1486. [CrossRef] [PubMed]

4. Lindner, M.; Maroschek, M.; Netherer, S.; Kremer, A.; Barbati, A.; Garcia-Gonzalo, J.; Seidl, R.; Delzon, S.; Corona, P.; Kolström, M.; et al. Climate change impacts, adaptive capacity, and vulnerability of European forest ecosystems. For. Ecol. Manag. 2010, 259, 698-709. [CrossRef]

5. Fensham, R.J.; Fairfax, R.J.; Ward, D.P. Drought-induced tree death in savanna. Glob. Chang. Biol. 2009, 15, 380-387. [CrossRef]

6. Mishra, A.K.; Singh, V.P. A review of drought concepts. J. Hydrol. 2010, 391, 202-216. [CrossRef]

7. Rivera, J.A.; Penalba, O.C.; Villalba, R.; Araneo, D.C. Spatio-temporal patterns of the 2010-2015 extreme hydrological drought across the Central Andes, Argentina. Water 2017, 9, 652. [CrossRef]

8. Zargar, A.; Sadiq, R.; Naser, B.; Khan, F.I. A review of drought indices. Environ. Rev. 2011, 19, 333-349. [CrossRef]

9. Duan, K.; Mei, Y. Comparison of meteorological, hydrological and agricultural drought responses to climate change and uncertainty assessment. Water Resour. Manag. 2014, 28, 5039-5054. [CrossRef]

10. Tallaksen, L.M.; Van Lanen, H.A.J. Hydrological Drought: Processes and Estimation Methods for Streamflow and Groundwater, 1st ed.; Elsevier: Amsterdam, The Netherlands, 2004.

11. Leng, G.; Tang, Q.; Rayburg, S. Climate change impacts on meteorological, agricultural and hydrological droughts in China. Glob. Planet. Chang. 2015, 126, 23-34. [CrossRef]

12. Haslinger, K.; Koffler, D.; Schöner, W.; Laaha, G. Exploring the link between meteorological drought and streamflow: Effects of climate-catchment interaction. Water Resour. Res. 2014, 50, 2468-2487. [CrossRef]

13. Van Loon, A.F.; Van Lanen, H.A.J. A process-based typology of hydrological drought. Hydrol. Earth Syst. Sci. 2012, 16, 1915-1946. [CrossRef]

14. Wang, W.; Ertsen, M.W.; Svoboda, M.D.; Hafeez, M. Propagation of drought: From meteorological drought to agricultural and hydrological drought. Adv. Meteorol. 2016, 2016, 6547209. [CrossRef]

15. Dai, A. Drought under global warming: A review. Wiley Interdiscip. Rev. Clim. Chang. 2011, 2, 45-65. [CrossRef]

16. Spinoni, J.; Naumann, G.; Vogt, J.; Barbosa, P. European drought climatologies and trends based on a multi-indicator approach. Glob. Planet. Chang. 2015, 127, 50-57. [CrossRef]

17. Bayissa, Y.; Tadesse, T.; Demisse, G.; Shiferaw, A.; Hong, Y.; Wen, Y.; Thenkabail, P.S. Evaluation of satellite-based rainfall estimates and application to monitor meteorological drought for the Upper Blue Nile Basin, Ethiopia. Remote Sens. 2017, 9, 669. [CrossRef]

18. Spinoni, J.; Barbosa, P.; Bucchignani, E.; Cassano, J.; Cavazos, T.; Christensen, J.H.; Christensen, O.B.; Coppola, E.; Evans, J.; Geyer, B.; et al. Future global meteorological drought hot spots: A study based on CORDEX data. J. Clim. 2020, 33, 3635-3661. [CrossRef]

19. Khanna, M. Hydrological Drought Indices; Indian Agriculture Research Institute: New Delhi, India, 2009.

20. Dalezios, N.R.; Blanta, A.; Spyropoulos, N.V. Assessment of remotely sensed drought features in vulnerable agriculture. Nat. Hazards Earth Syst. Sci. 2012, 12, 3139-3150. [CrossRef]

21. Vicente-Serrano, S.M.; López-Moreno, J.I.; Beguería, S.; Lorenzo-Lacruz, J.; Azorin-Molina, C.; Morán-Tejeda, E. Accurate computation of a streamflow drought index. J. Hydrol. Eng. 2011, 17, 318-332. [CrossRef]

22. Manton, M.J.; Della-Marta, P.M.; Haylock, M.R.; Hennessy, K.J.; Nicholls, N.; Chambers, L.E.; Collins, D.A.; Daw, G.; Finet, A.; Gunawan, D.; et al. Trends in extreme daily rainfall and temperature in Southeast Asia and the South Pacific: 1961-1998. Int. J. Climatol. 2001, 21, 269-284. [CrossRef]

23. Nicholls, N.; Murray, W. Workshop on indices and indicators for climate extremes: Asheville, NC, USA, 3-6 June 1997 breakout group B: Precipitation. In Weather and Climate Extremes: Changes, Variations and a Perspective from the Insurance Industry; Karl, T.R., Nicholls, N., Ghazi, A., Eds.; Springer: Dordrecht, The Netherlands, 1999; pp. 23-29.

24. Mckee, T.B.; Doesken, N.J.; Kleist, J. The relationship of drought frequency and duration to the time scales. In Proceedings of the Eighth Conference on Applied Climatology, Anaheim, CA, USA, 17-22 January 1993; pp. 17-22.

25. Van Rooy, M. A Rainfall Anomally Index Independent Of Time And Space. Weather Bur. S. Afr. 1965, 14, 43-48.

26. Guttman, N.B. Accepting the standardized precipitation index: A calculation algorithm. J. Am. Water Resour. Assoc. 1999, 35, 311-322. [CrossRef]

27. Wu, H.; Svoboda, M.D.; Hayes, M.J.; Wilhite, D.A.; Wen, F. Appropriate application of the standardized precipitation index in arid locations and dry seasons. Int. J. Climatol. 2007, 27, 65-79. [CrossRef]

28. Moreira, E.E. SPI drought class prediction using log-linear models applied to wet and dry seasons. Phys. Chem. Earth Parts A/B/C 2016, 94, 136-145. [CrossRef]

29. Zhang, Q.; Xiao, M.; Singh, V.P.; Chen, X. Copula-based risk evaluation of droughts across the Pearl River basin, China. Theor. Appl. Climatol. 2013, 111, 119-131. [CrossRef] 
30. Pramudya, Y.; Onishi, T. Assessment of the Standardized Precipitation Index (SPI) in Tegal City, Central Java, Indonesia. IOP Conf. Ser. Earth Environ. Sci. 2018, 129, 012019. [CrossRef]

31. Hayes, M.J. Drought Indices. What Is Drought? National Drought Mitigation Center: Lincon, NE, USA, 2006.

32. Mishra, A.K.; Desai, V.R. Spatial and temporal drought analysis in the Kansabati river basin, India. Int. J. River Basin Manag. 2010, 3, 43-52. [CrossRef]

33. Heinrich, G.; Gobiet, A. The future of dry and wet spells in Europe: A comprehensive study based on the ENSEMBLES regional climate models. Int. J. Climatol. 2012, 32, 1951-1970. [CrossRef]

34. Vidal, J.P.; Martin, E.; Kitova, N.; Najac, J.; Soubeyroux, J.M. Evolution of spatio-temporal drought characteristics: Validation, projections and effect of adaptation scenarios. Hydrol. Earth Syst. Sci. 2012, 16, 2935-2955. [CrossRef]

35. Tilahun, K. Analysis of rainfall climate and evapo-transpiration in arid and semi-arid regions of Ethiopia using data over the last half a century. J. Arid Environ. 2006, 64, 474-487. [CrossRef]

36. Keyantash, J.; Dracup, J.A. The quantification of drought: An evaluation of drought indices. Bull. Am. Meteorol. Soc. 2002, 83, 1167-1180. [CrossRef]

37. Vasiliades, L.; Dalezios, N.R.; Loukas, A.; Vasiliades, L.; Dalezios, N.R. Intercomparison of meteorological drought indices for drought assessment and monitoring in Greece prediction. In Proceedings of the 8th International Conference on Environmental Science and Technology, Lemnos Island, Greece, 8-10 September 2003; pp. 484-491.

38. Hänsel, S.; Schucknecht, A.; Matschullat, J. The Modified Rainfall Anomaly Index (mRAI)—Is this an alternative to the Standardised Precipitation Index (SPI) in evaluating future extreme precipitation characteristics? Theor. Appl. Climatol. 2016, 123, 827-844. [CrossRef]

39. Adhikari, S. Drought impact and adaptation strategies in the Mid-Hill farming system of western Nepal. Environments 2018, 5, 101. [CrossRef]

40. Joshi, G.R. Agricultural Economy of Nepal: Development Challenges and Opportunities; Nepal Policy Research Centre: Kathmandu, Nepal, 2018.

41. United Nations Development Programme (UNDP). Country Report Climate Risk Management for Agriculture in Nepal: Regional Integrated Multi-Hazard Early Warning System for Africa and Asia; United Nations Development Programme (UNDP): New York, NY, USA, 2013.

42. Ghimire, Y.N.; Shivakoti, G.P.; Perret, S.R. Household-level vulnerability to drought in hill agriculture of Nepal: Implications for adaptation planning. Int. J. Sustain. Dev. World Ecol. 2010, 17, 225-230. [CrossRef]

43. Talchabhadel, R.; Karki, R.; Yadav, M.; Maharjan, M.; Aryal, A.; Thapa, B.R. Spatial distribution of soil moisture index across Nepal: A step towards sharing climatic information for agricultural sector. Theor. Appl. Climatol. 2019, 137, 3089-3102. [CrossRef]

44. Talchabhadel, R.; Karki, R.; Thapa, B.R.; Maharjan, M.; Parajuli, B. Spatio-temporal variability of extreme precipitation in Nepal. Int. J. Climatol. 2018, 38, 4296-4313. [CrossRef]

45. Sigdel, M.; Ikeda, M. Spatial and temporal analysis of drought in Nepal using Standardized Precipitation Index and its relationship with climate indices. J. Hydrol. Meteorol. 2010, 7, 59-74. [CrossRef]

46. Dahal, P.; Shrestha, N.S.; Shrestha, M.L.; Krakauer, N.Y.; Panthi, J.; Pradhanang, S.M.; Jha, A.; Lakhankar, T. Drought risk assessment in central Nepal: Temporal and spatial analysis. Nat. Hazards 2016, 80, 1913-1932. [CrossRef]

47. Central Bureau of Statistics (CBS). National Population and Housing Census; Central Bureau of Statistics (CBS): Kathmandu, Nepal, 2011.

48. Hayes, M.J.; Svoboda, M.D.; Wilhite, D.A.; Vanyarkho, O.V. Monitoring the 1996 drought using the Standardized Precipitation Index. Bull. Am. Meteorol. Soc. 1999, 80, 429-438. [CrossRef]

49. Vicente-Serrano, S.M.; Beguería, S.; López-Moreno, J.I. A multiscalar drought index sensitive to global warming: The standardized precipitation evapotranspiration index. J. Clim. 2017, 23, 1696-1718. [CrossRef]

50. Wilks, D.S. Statistical Methods in the Atmospheric Sciences, 2nd ed.; Academic Press: Cambridge, MA, USA, 2011 ; ISBN 0128165278.

51. Lloyd-Hughes, B.; Saunders, M.A. A drought climatology for Europe. Int. J. Climatol. 2002, 22, 1571-1592. [CrossRef]

52. Thom, H.C.S. A Note on the Gamma Distribution. J. Franklin Inst. 1958, 86, 1-8. [CrossRef]

53. Fernandes, D.S.; Heinemann, A.B.; da Paz, R.L.; Amorim, A.D.O.; Cardoso, A.S. Índices Para a Quantificação da Seca; Embrapa Arroz e Feijão-Documentos (INFOTECA-E): Santo Antônio de Goiás, Brazil, 2009.

54. De Araújo, L.E.; de Moraes Neto, J.M.; de Sousa, F.D.A.S. Classification of annual rainfall and the rainy quarter of the year in the Paraíba river basin using Rain Anomaly Index (RAI). An Interdiscip. J. Appl. Sci. 2009, 4, 93-110. [CrossRef]

55. Sanches, F.O.; Verdum, R.; Fisch, G. The Rainfall Anomaly Index (RAI) in the evolution of annual precipitation in the Alegrete/RS. Caminhos Geogr. 2014, 15, 73-84.

56. dos Santos, E.C.A.; de Araújo, L.E.; dos Marcelino, A.S. Climatic analysis of the Mamanguape River Basin. Rev. Bras. Eng. Agrícola Ambient. 2015, 19, 9-14. [CrossRef]

57. Wang, S.Y.; Yoon, J.H.; Gillies, R.R.; Cho, C. What caused the winter drought in western Nepal during recent years? J. Clim. 2013, 26, 8241-8256. [CrossRef]

58. Hamal, K.; Sharma, S.; Pokharel, B.; Shrestha, D.; Talchabhadel, R.; Shrestha, A.; Khadka, N. Changing pattern of drought in Nepal and associated atmospheric circulation. Atmos. Res. 2021, 262, 105798. [CrossRef]

59. Khatiwada, K.R.; Pandey, V.P. Characterization of hydro-meteorological drought in Nepal Himalaya: A case of Karnali River Basin. Weather Clim. Extrem. 2019, 26, 100239. [CrossRef] 
60. Cavus, Y.; Aksoy, H. Spatial drought characterization for Seyhan River Basin in the Mediterranean region of Turkey. Water 2019, 11, 1331. [CrossRef]

61. Meshram, S.G.; Gautam, R.; Kahya, E. Drought analysis in the Tons River Basin, India during 1969-2008. Theor. Appl. Climatol. 2018, 132, 939-951. [CrossRef]

62. Gumma, M.K.; Gauchan, D.; Nelson, A.; Pandey, S.; Rala, A. Temporal changes in rice-growing area and their impact on livelihood over a decade: A case study of Nepal. Agric. Ecosyst. Environ. 2011, 142, 382-392. [CrossRef] 